\title{
1 Amyloid-beta mediates homeostatic synaptic plasticity
}

2 Christos Galanis ${ }^{1,2}$, Meike Fellenz ${ }^{3}$, Denise Becker ${ }^{3, *}$, Charlotte Bold ${ }^{4}$, Stefan F.

3 Lichtenthaler ${ }^{5,6,7}$, Ulrike C. Müller ${ }^{4}$, Thomas Deller ${ }^{3}$, Andreas Vlachos ${ }^{1,8+}$

\footnotetext{
${ }^{1}$ Department of Neuroanatomy, Institute of Anatomy and Cell Biology, Faculty of Medicine, University of Freiburg, Freiburg, Germany

${ }^{2}$ Faculty of Biology, University of Freiburg, Freiburg, Germany

${ }^{3}$ Institute of Clinical Neuroanatomy, Dr. Senckenberg Anatomy, Neuroscience Center, Goethe-University Frankfurt, Frankfurt, Germany

${ }^{4}$ Institute of Pharmacy and Molecular Biotechnology, Bioinformatics and Functional Genomics. Ruprecht-Karls University, Heidelberg, Germany

${ }^{5}$ German Center for Neurodegenerative Diseases (DZNE), Munich, Germany

${ }^{6}$ Neuroproteomics, School of Medicine, Klinikum Rechts der Isar, Technical University Munich, Munich, Germany

${ }^{7}$ Munich Cluster for Systems Neurology (SyNergy), Munich, Germany

${ }^{8}$ Center for Basics in Neuromodulation (NeuroModulBasics), Faculty of Medicine. University of Freiburg, Freiburg, Germany

* current address: Department of Neurology, University Hospital of Zurich, Zurich, Switzerland.
}

Abbreviated title: Abeta and synaptic scaling

${ }^{\dagger}$ Corresponding author

\author{
Andreas Vlachos, M.D. \\ Albertstr. 17 \\ 79104 Freiburg, Germany \\ Phone: +49(0)761 2035056 \\ Fax: +49 (0)761 20135054 \\ Email: andreas.vlachos@ anat.uni-freiburg.de
}

Number of pages: 36

Figures: 9; Tables: 0; Multimedia and 3D models: 0

Words in title: 5; Characters in abbreviated title: 26

Words in abstract:145; Introduction: 574; Discussion: 1353 


\section{ABSTRACT}

The physiological role of the amyloid-precursor protein (APP) is insufficiently understood. Recent work has implicated APP in the regulation of synaptic plasticity. Substantial evidence exists for a role of APP and its secreted ectodomain APPs $\alpha$ in Hebbian plasticity. Here, we addressed the relevance of APP in homeostatic synaptic plasticity using organotypic tissue cultures of $A P P^{-/}$mice. In the absence of APP, dentate granule cells failed to strengthen their excitatory synapses homeostatically. Homeostatic plasticity is rescued by amyloid- $\beta$ (A $\beta$ ) and not by APPs $\alpha$, and it is neither observed in $A P P^{+/+}$tissue treated with $\beta$ - or $\gamma$-secretase inhibitors nor in synaptopodin-deficient cultures lacking the $\mathrm{Ca}^{2+}$-dependent molecular machinery of the spine apparatus. Together, these results suggest a role of APP processing via the amyloidogenic pathway in homeostatic synaptic plasticity, representing a function of relevance for brain physiology as well as for brain states associated with increased $A \beta$ levels.

KEYWORDS: Alzheimer's disease, APP processing, secretases, amyloid-beta, sAPPalpha, Hebbian plasticity, homeostatic plasticity 


\section{INTRODUCTION}

In recent years, considerable effort has been directed to better understanding the pathogenic role of APP and its cleavage products in neurodegeneration (Bohm et al., 2015). It has been proposed that the accumulation and deposition of "synaptotoxic" $\mathrm{A} \beta$ peptides, which are produced by sequential cleavage of APP by $\beta$ - and $\gamma$-secretase (Lichtenthaler et al., 2011), are responsible for synapse loss, which is regarded as the significant structural hallmark of cognitive decline in Alzheimer's diseases. In comparison, the physiological functions of cleavage products generated along the "amyloidogenic pathway", which are also produced in low concentrations in the healthy brain (Cirrito et al., 2003; Seubert et al., 1992; Shoji et al., 1992), are incompletely understood.

Studies employing mouse mutants lacking APP or APP-gene family members (Herms et al., 2004; Magara et al., 1999; Ring et al., 2007; von Koch et al., 1997; Zheng et al., 1995), have shed new light on the role of APP in neuronal migration, synaptogenesis, and synaptic structure and function (Müller et al., 2017). Specifically, alterations in dendritic arborization and spine densities have been reported in pyramidal cells of $A P P^{-/-}$mice, and these changes are accompanied by defects in the ability of neurons to express long-term potentiation (LTP) of excitatory synaptic strength and alterations in spatial learning [e.g., (Dawson et al., 1999; Li et al., 1996; Muller et al., 1994; Ring et al., 2007; Tyan et al., 2012; Zheng et al., 1995) reviewed in (Ludewig and Korte, 2016; Müller et al., 2017)]. Several of the reported phenotypes of $A P P^{--}$mice are rescued by the APP secreted ectodomain alpha [APPs $\alpha$, e.g., (Hick et al., 2015; Richter et al., 2018; Tan et al., 2018; Weyer et al., 2014)]. Therefore, it has been proposed that APP could play an important role in neuronal structural and functional plasticity under physiological conditions through the "non-amyloidogenic pathway" which produces APPs $\alpha$. The physiological function of amyloid- $\beta$ (A $\beta$ ) has, however, remained enigmatic. 
In an attempt to learn more about the role of APP and its cleavage products in synaptic plasticity, we here tested for its significance in another major plasticity mechanism (i.e., homeostatic synaptic plasticity). The ability of neurons to adjust their synaptic strength in a compensatory manner is considered to be fundamental for physiological brain function (Styr and Slutsky, 2018; Turrigiano, 1999). It is also a relevant compensatory mechanism in the context of brain diseases and a promising therapeutic target (Andre et al., 2018; Smith-Dijak et al., 2019). In contrast to Hebbian synaptic plasticity, e.g., LTP, homeostatic plasticity is based on negative feedback mechanisms (Lisman, 2017; Turrigiano, 2008). Meanwhile, several molecular players have been identified that control homeostatic synaptic plasticity (Cingolani et al., 2008; Goddard et al., 2007; Stellwagen and Malenka, 2006; Sun and Turrigiano, 2011; Walters and Josselyn, 2019). Recently, a potential role of APP in homeostatic synaptic plasticity has been discussed (Andre et al., 2018; Hoe et al., 2012; Jang and Chung, 2016; Styr and Slutsky, 2018). However, the mechanistic link between APP and homeostatic plasticity remains unclear because homeostatic plasticity could be induced by APP and its cleavage products or indirectly by synapse loss and cell death [i.e., denervationinduced homeostatic adaptation; e.g., (Deller and Frotscher, 1997; Steward, 1994; Vlachos et al., 2012; Vlachos et al., 2013)]. Here, we studied the role of APP in non-diseased brain tissue and report an essential role of $\mathrm{A} \beta$ in homeostatic plasticity of excitatory neurotransmission, suggesting that this could be one of the major physiological functions of $A \beta$ in the normal brain. 


\section{RESULTS}

\section{Homeostatic synaptic plasticity is not observed in dentate granule cells of APP-deficient}

\section{entorhinal-hippocampal tissue cultures}

Considering the role of the hippocampal formation and specifically the dentate gyrus in memory formation (Aimone et al., 2011; Friedman and Goldman-Rakic, 1988), 3-week-old ( $\geq 18$ days in vitro; div) organotypic tissue cultures containing the entorhinal cortex and the hippocampus were prepared from $\mathrm{APP}^{+/+}$and $A P P^{-/-}$mice-including age- and time-matched $A P P^{+/+}$littermates obtained from $A P P^{+/-}$intercrossing (Figure $1 A, B$ ). Tissue cultures were treated with tetrodotoxin (TTX; $2 \mu \mathrm{M} ; 2$ days) to induce homeostatic synaptic plasticity, and a-amino-3-hydroxy-5-methyl-4-isoxazolepropionic acid (AMPA) receptor-mediated miniature excitatory postsynaptic currents (mEPSCs) were recorded from individual dentate granule cells (Figure 1C) to assess compensatory (i.e., homeostatic) synaptic changes.

In line with previous work [e.g., (Echegoyen et al., 2007; Kim and Tsien, 2008; Strehl et al., 2018; Turrigiano et al., 1998; Vlachos et al., 2013)], a homeostatic increase in excitatory synaptic strength (i.e., a robust increase in mEPSC amplitudes) was observed in the wild-type tissue cultures (Figure $1 D, E$ ). In $A P P^{-/}$preparations, no significant changes in mEPSC properties were observed in dentate granule cells (Figure $1 F, G$ ). Specifically, mean mEPSC amplitude was $11.5 \pm 0.3 \mathrm{pA}$ in vehicle-only-treated and $11.8 \pm 0.4 \mathrm{pA}$ TTX-treated $A P P^{-/}$ dentate granule cells ( $\mathrm{p}=0.4$; Mann-Whitney-test $)$.

In an attempt to rescue the ability of granule cells to express homeostatic synaptic plasticity, $A P P^{-/}$tissue cultures were transfected with a bicistronic adeno-associated viral vector expressing full-length murine APP (flAPP) and membrane-anchored Venus linked by a T2A site under the control of the neuronal synapsin promoter (AAV-Syn-flAPP-T2A-Venus; Figure $1 H$ ). Cultures were transduced at $4-5$ div and allowed to mature for at least 18 div before experimental assessment. A significant compensatory increase in mEPSC amplitudes from $10.5 \pm 0.3 \mathrm{pA}$ to $17.5 \pm 0.7 \mathrm{pA}(\mathrm{p}<0.001$; Mann-Whitney-test; Figure $1 I$ ) was observed 
in the TTX-group, while increased mEPSC frequencies were observed in the untreated cultures reduced after TTX treatment (Figure 1I). We conclude from these results that postnatal expression of APP is required for TTX-induced homeostatic scaling of excitatory synapses to occur in cultured dentate granule cells.

Based on our recent work (Lenz et al., 2019), we also tested for changes in inhibitory synaptic strength, and we did not detect TTX-induced changes in miniature inhibitory postsynaptic currents (mIPSCs) of dentate granule cells, either in $A P P^{+/+}$or $A P P^{-/}$tissue cultures (Figure S1). Hence, we focused on the role of APP in excitatory synaptic scaling.

\section{No significant alterations in basic functional and structural properties of APP-deficient}

\section{dentate granule cells}

To test whether alterations in baseline synaptic activity explain the inability of $A P P^{-/}$granule cells to express homeostatic excitatory synaptic plasticity, spontaneous excitatory and inhibitory postsynaptic currents were recorded in a different set of 3-week-old tissue cultures (Figure $2 A-D$ ). No significant differences between the two genotypes were observed in these experiments. Similarly, the input-output properties of dentate granule cells (Figure $2 E, F$ ), as well as basic properties of action potentials (Figure $2 G$ ), were not significantly different between the two groups.

We also tested for variations in basic structural properties of granule cells between $A P P^{+/+}$and $A P P^{-/-}$preparations. As shown in Figure S2, an assessment of total dendritic branch length and Sholl analysis revealed no significant differences between the genotypes (Figure $3 A-C$ ). We also did not find any significant differences in spine densities (Figure $3 D-$ $F)$, and synapses were regularly observed in electron microscopy cross-sections of recorded and post-hoc stained $A P P^{-/}$dentate granule cells (Figure $3 F$ ). Hence, basic functional and structural alterations do not readily explain the inability of $A P P^{-/}$granule cells to scale their excitatory synapses. 
A secreted factor rescues the ability of APP-deficient dentate granule cells to express

\section{homeostatic synaptic plasticity}

In our viral transduction experiments, in which we used flAPP to rescue homeostatic synaptic APP on TTX-induced homeostatic synaptic plasticity.

To test this hypothesis, $A P P^{-/-}$tissue was cultured with $5 A P P^{+/+}$cultures on the same

membrane insert as shown in Figure $4 A$. In these experiments, a significant increase in excitatory synaptic strength was detected in dentate granule cells of TTX-treated $A P P^{-/}$ cultures (Figure $4 B, C$ ). We conclude that a secreted molecular signal originating from $A P P^{+/+}$tissue is sufficient to rescue the ability of granule cells in the $A P P^{-/}$cultures to express TTX-induced homeostatic synaptic plasticity. The results of these experiments also act as a receptor for signaling pathways relevant for TTX-induced excitatory synaptic scaling).

\section{APPsa does not rescue homeostatic synaptic plasticity in APP-deficient preparations}

153 Previous work revealed that APPs $\alpha$ rescues several phenotypes observed in $A P P^{-/}$mice, including alterations in Hebbian synaptic plasticity [i.e., LTP (e.g., (Fol et al., 2016; Hick et be the secreted factor that rescues the ability of $A P P^{-/-}$granule cells to express homeostatic synaptic plasticity in our experiments (c.f., Figure 4).

159 hippocampal slices [10 nM; (Hick et al., 2015)], and TTX-induced synaptic scaling was 
$B$ ), thus confirming once more our major finding (i.e., alterations in homeostatic synaptic plasticity of $A P P^{-/-}$preparations).

We next resorted to adeno-associated viral transduction of secreted APPs $\alpha$ (AAV-Syn-

in $A P P^{-/-}$mice (Fol et al., 2016). Again, in our experimental setting no compensatory increase in mean mEPSC amplitude was observed after TTX treatment as compared to age- and timematched vehicle-only-treated APPs $\alpha$ transfected $A P P^{-/}$tissue cultures (Figure $5 C, D$ ). group in these experiments (Figure 5D). Notably, these experiments also indicated that viral transduction per se does not rescue the ability of $A P P^{-/}$granule cells to express homeostatic synaptic plasticity (c.f., Figure $1 H, I$ ).

Finally, tissue cultures from APPs $\alpha-K I$ mice were prepared (Ring et al., 2007), which express APPs $\alpha$ constitutively while lacking transmembrane APP and A $\beta$; this represents another approach for rescuing LTP (Ring et al., 2007). Because in these experiments we also did not observe homeostatic plasticity (Figure 5E, F), we conclude that APPs $\alpha$ does not rescue TTX-induced homeostatic synaptic plasticity of dentate granule cells in $\mathrm{APP}^{-/-}$tissue LTP. synaptic plasticity

We next tested for the effects of endogenous APPs $\alpha$ by treating wild-type tissue cultures with TTX ( $2 \mu \mathrm{M} ; 2$ days) in the presence of a specific antibody that binds APPs $\alpha$ [i.e., the Nterminal APP-E1 domain; JRD32; $1.3 \mu \mathrm{g} / \mathrm{ml}$; (Hick et al., 2015)]. As shown in Figure 6A, a compensatory increase in mEPSC amplitudes was observed in these experiments, thus 
providing additional evidence that APPs $\alpha$ is not involved in mediating homeostatic synaptic plasticity.

Because treatment with recombinant APPs $\alpha(10 \mathrm{nM})$ also did not cause aberrant "over"scaling in $\mathrm{APP}^{+/+}$dentate granule cells (Figure $6 \mathrm{~B}$ ), together with the experiments carried out in $A P P^{-/}$cultures (c.f., Figure 5), we are confident to conclude that APPs $\alpha$ is not a major regulator of homeostatic synaptic plasticity (this study) whereas it does promote LTP [e.g., (Fol et al., 2016; Hick et al., 2015; Richter et al., 2018; Ring et al., 2007)].

\section{A $\beta$ rescues homeostatic synaptic plasticity in APP-deficient preparations}

We then considered the amyloidogenic processing pathway and the potential for $A \beta$ involvement in mediating homeostatic synaptic plasticity. Another set of $A P P^{-/}$tissue cultures was treated for 2 days with TTX and with a synthetic A $\beta$ protein fragment $1-42[1.5 \mu \mathrm{M}$; (Novotny et al., 2016)]. Notably, a full-sized homeostatic synaptic scaling response was observed in these experiments, whereas 2 days of $A \beta_{1-42}$ treatment had no effect on baseline mEPSC amplitudes and frequencies (Figure $7 A$ ): in the presence of $A \beta_{1-42,}$ mEPSC amplitudes increased from $10.9 \pm 0.5 \mathrm{pA}$ to $16.8 \pm 0.9 \mathrm{pA}$ after $2 \mathrm{~d}$ TTX treatment $(\mathrm{p}<0.001$; Kruskal-Wallis-test followed by Dunn's post-hoc test). Because similar experiments with the synthetic $A \beta$ protein fragment $42-1(1.5 \mu \mathrm{M})$ did not show any significant changes in mEPSC properties (Figure $7 B$ ), we conclude that the application of exogenous $A \beta_{1-42}$ rescues TTX-induced homeostatic synaptic plasticity in $A P P^{-/-}$preparations.

\section{Pharmacological inhibition of $\beta$-secretases in wild-type tissue cultures blocks}

\section{homeostatic synaptic plasticity}

Due to the fact that endogenous A $\beta$ is produced by sequential cleavage of APP by $\beta$ - and $\gamma$ secretases (Chow et al., 2010; Zheng and Koo, 2011), we next hypothesized that pharmacological inhibition of $\beta$-secretases (i.e., blocking the first step of the amyloidogenic 
processing pathway) should impede the ability of wild-type dentate granule cells to express TTX-induced synaptic scaling. Accordingly, wild-type cultures were treated with TTX (2 $\mu \mathrm{M}$; 2 days) and with BACE inhibitor C3 [20 $\mu \mathrm{M}$; 2 days;(Stachel et al., 2004)]. Pharmacological inhibition of $\beta$-secretases had no apparent effect on baseline mEPSC recordings, and a TTX-induced increase in mEPSC amplitudes was not observed. Exposure to $\mathrm{A} \beta_{1-42}(1.5 \mu \mathrm{M})$ together with BACE inhibitor $\mathrm{C} 3$ restored the ability of wild-type dentate granule cells to express homeostatic synaptic scaling (Figure $7 C$ ). Furthermore, in the presence of BACE inhibitor C3, TTX-induced synaptic scaling was not observed in $A P P^{-/}$ preparations co-cultured with $5 \mathrm{APP}^{+/+}$cultures on the same membrane insert (Figure $7 \mathrm{D}$; c.f., Figure 4). These results suggest that APP/A $\beta$ is part of an endogenous signaling pathway that mediates homeostatic synaptic plasticity.

\section{Pharmacological inhibition of $\gamma$-secretases in wild-type tissue cultures blocks}

\section{homeostatic synaptic plasticity}

BACE not only cleaves APP but also targets several other substrates in the nervous system (Barao et al., 2016). Although $A \beta_{1-42}$ rescued homeostatic synaptic plasticity in BACE inhibitor C3-treated wild-type cultures, we decided to err on the side of caution. Accordingly, another series of experiments was carried out using the $\gamma$-secretase inhibitor Begacestat [GSI953; $1 \mu \mathrm{M}$; (Martone et al., 2009)] to block the second enzymatic step of the amyloidogenic processing pathway. As shown in Figure $7 E$, a compensatory increase in mEPSC amplitudes was not observed in the presence of Begacestat after TTX treatment. Again, $A \beta_{1-42}$ rescued the ability of wild-type dentate granule cells to express homeostatic synaptic plasticity in the presence of the $\gamma$-secretase inhibitor (Figure $7 E$ ). Consistent with these findings, $A \beta$ sandwich-ELISA confirmed that endogenous $A \beta_{1-42}$ is significantly reduced upon pharmacologic inhibition of $\beta$ - or $\gamma$-secretases in our experimental setting [control, $115 \pm 10$ 
$\mathrm{pg} / \mathrm{ml}$; BACE inhibitor $\mathrm{C} 3,14 \pm 0.9 \mathrm{pg} / \mathrm{ml}$; Begacestat, $4 \pm 0.1 \mathrm{pg} / \mathrm{ml}$; medium harvested form $\mathrm{n}=3$ - 6 wells per group; $\mathrm{p}<0.001$; one-way ANOVA].

\section{Scavenging endogenous $A \beta$ with a specific antibody blocks homeostatic synaptic} plasticity in wild-type tissue cultures

Finally, we carried out experiments in wild-type cultures using an antibody that binds granule cells were observed in these experiments (control, $10.9 \pm 0.4 \mathrm{pA}$; TTX $10.6 \pm 0.3 \mathrm{pA}$ $\mathrm{n}=15$ cells per group; $\mathrm{p}=0.62$; Mann-Whitney-test). Similarly, in the experimental setting in which $A P P^{-/-}$tissue was co-cultured with $A P P^{+/+}$cultures, again, no TTX-induced synaptic scaling was observed in the $A P P^{-/}$cultures in the presence of the anti-A $\beta$ antibody (Figure $7 F$; c.f., Figure 4).

Taken together, we conclude that APP is a key regulator of homeostatic synaptic plasticity and that $A \beta$-dependent signaling pathways account for the ability of cultured dentate granule cells to express TTX-induced homeostatic plasticity of excitatory synapses.

Pharmacologic inhibition of NMDA-Rs rescues homeostatic synaptic plasticity in APP-

\section{deficient preparations}

What are the downstream signaling pathways of APP/A $\beta$ mediated homeostatic synaptic plasticity? Previous work revealed that $\mathrm{A} \beta$ affects Hebbian plasticity via modulation of $\mathrm{N}$ methyl-D-aspartate receptors [NMDA-R; (Chen et al., 2002; Snyder et al., 2005; Zhang et al., 2009)]. Considering the role of NMDA-R in homeostatic synaptic plasticity [i.e., NMDA-R inhibition triggers synaptic up-scaling; (Sutton et al., 2006)], we tested whether pharmacologic inhibition of NMDA-R rescues homeostatic synaptic plasticity in the absence of $\mathrm{A} \beta$ (i.e., in $A P P^{-/-}$tissue cultures). In the presence of the NMDA-R antagonist D-APV (50 
$\mu \mathrm{M}$ ), a significant increase in mEPSC amplitudes was noted in TTX-treated $\mathrm{APP}^{-/}$granule cells (Figure $8 A, B$ ). Interestingly, recordings of NMDA-R-mediated mEPSCs showed no significant differences between $\mathrm{APP}^{-/-}$and $\mathrm{APP}^{+/+}$granule cells $\left(\mathrm{APP}^{+/+}, 17.6 \pm 0.7 \mathrm{pA} ; \mathrm{APP}^{-/-}\right.$ $17.0 \pm 0.6 \mathrm{pA} ; \mathrm{n}=9$ and 10 cells, respectively; $\mathrm{p}=0.66 ;$ Mann-Whitney test), confirming once more that basic functional differences between the two genotypes do not trivially explain our major findings (c.f., Figures 2 and 3). These results indicate that $A \beta$ acts on intracellular $\mathrm{Ca}^{2+}$ sensors or effectors, which respond to the TTX-induced reduction of intracellular $\mathrm{Ca}^{2+}$ in our experiments.

\section{Pharmacologic inhibition of CamKII rescues homeostatic synaptic plasticity in APP-}

\section{deficient preparations}

$\mathrm{A} \beta$ has been linked to inactivation of calcium/calmodulin-dependent protein kinase II [CamKII; (Gu et al., 2009; Townsend et al., 2007; Zhao et al., 2004); but see (Opazo et al., 2018)]. Hence, we reasoned that in the absence of APP/A $\beta$, pharmacological inhibition of CamKII might also rescue TTX-induced synaptic scaling. Indeed, increased mEPSC amplitudes were observed in $A P P^{-/-}$cultures upon TTX treatment in the presence of KN-93 (5 $\mu \mathrm{M})$, but not with the inactive analogue $\mathrm{KN}-92(5 \mu \mathrm{M}$; Figure $8 C$ ). Hence, NMDA-Rmediated CaMKII-dependent downstream signaling pathways seem to be involved in APP/A $\beta$-mediated homeostatic synaptic plasticity.

\section{Role of synaptopodin in APP/Aß mediated homeostatic synaptic plasticity}

In previous work, we demonstrated that the actin-binding molecule synaptopodin, which is a marker and essential component of the $\mathrm{Ca}^{2+}$-storing spine apparatus organelle (Deller et al., 2003), is required for the expression of homeostatic synaptic plasticity (Vlachos et al., 2013). In this context, a $\mathrm{Ca}^{2+}$-dependent compensatory increase in synaptopodin clusters was observed, consistent with a negative feedback mechanism that mediates homeostatic synaptic 
plasticity (Vlachos et al., 2013). Notably, an association between synaptopodin and peptides corresponding to CamKII $\alpha$ and CamKII $\beta$ has been recently reported (Konietzny et al., 2019).

To test whether activity-dependent changes of synaptopodin are part of a negative feedback mechanism that requires APP/A $\beta$-dependent signalling, $A P P^{-/}$cultures were once again treated with TTX $(2 \mu \mathrm{M} ; 2 \mathrm{~d})$. Immunostained synaptopodin clusters were assessed in the outer molecular layer of the dentate gyrus, and the previously reported compensatory increase in synaptopodin cluster sizes was not observed in TTX-treated $A P P^{-/}$cultures [c.f., (Vlachos et al., 2013)]. We then tested whether in the presence of $\mathrm{A} \beta_{1-42}$, TTX-induced changes in synaptopodin clusters are triggered. Indeed, the same protocol that rescues homeostatic synaptic plasticity in $A P P^{-/}$preparations also induces synaptopodin changes similar to that observed in wild-type cultures (Figure $8 F$ ).

Does pharmacological inhibition of NMDA-Rs and CamKII rescue homeostatic synaptic scaling-associated changes in synaptopodin cluster properties of $A P P^{-/}$cultures? As shown in Figure $8 \mathrm{~F}$, in the presence of D-APV $(50 \mu \mathrm{M})$ or KN93 $(5 \mu \mathrm{M})$, a significant increase in synaptopodin clusters was observed in response to TTX ( $2 \mu \mathrm{M}, 2$ days). These results indicate that $\mathrm{APP} / \mathrm{A} \beta$ is part of a $\mathrm{Ca}^{2+}$-dependent negative feedback mechanism that regulates synaptopodin cluster properties in an NMDA-R- and CamKII-dependent manner.

Finally, based on the observation that $A \beta_{1-42}$ rescues TTX-induced homeostatic synaptic plasticity, we tested for the effects of $A \beta_{1-42}$ in synaptopodin-deficient dentate granule cells, which do not form spine apparatus organelles and show defects in homeostatic synaptic plasticity (Vlachos et al., 2013). Whereas the previously reported deficit in TTX-induced homeostatic synaptic plasticity was reproduced in these experiments, $A \beta_{1-42}$ did not rescue homeostatic synaptic plasticity in $S Y N P O^{-/-}$dentate granule cells (Figure $8 G$ ). Taken together, we propose that synaptopodin is one of the downstream molecular targets required for APP/A $\beta$-mediated homeostatic synaptic plasticity. 


\section{DISCUSSION}

We regard the significant finding of this study to be the discovery of a previously unknown APP/A $\beta$ phenotype that becomes salient after network activity is altered (i.e., blocked by TTX for a prolonged period of time). Under these conditions, $A P P^{-/}$dentate granule cells do not scale their excitatory synapses in a homeostatic manner. Surprisingly, this plasticity phenotype does not depend on APPs $\alpha$, which is generated from APP via non-amyloidogenic processing and which has been linked to Hebbian plasticity, but on $\mathrm{A} \beta$, which is generated from APP via processing along the amyloidogenic pathway. Consistent with this observation, pharmacologic inhibition of $\beta$ - and $\gamma$-secretases as well as scavenging endogenous $A \beta$ with antibodies blocked TTX-induced synaptic scaling in wild-type tissue cultures. A $\beta$-dependent synaptic scaling required modulation of downstream $\mathrm{Ca}^{2+}$-dependent signaling pathways, including NMDA-Rs and CamKII, as well as synaptopodin-a molecule essential for the formation of the $\mathrm{Ca}^{2+}$-storing spine apparatus. Together, these results reveal a direct involvement of amyloidogenic APP processing and A $\beta$ in homeostatic synaptic plasticity. This involvement raises the intriguing possibility that changes in the balance of APP processing along the two major APP-processing pathways could also lead to changes in the balance of Hebbian and homeostatic plasticity in the brain (Figure 9).

Studies employing mouse mutants lacking APP or APP-gene family members have established a firm link between APP and the ability of neurons to express synaptic plasticity (Müller et al., 2017). Specifically, the ability of neurons to express LTP of excitatory neurotransmission is impaired in aged $A P P^{-/-}$mice [e.g., (Dawson et al., 1999; Ring et al., 2007; Seabrook et al., 1999; Tyan et al., 2012)]. APPs $\alpha$ could rescue this deficit [e.g., (Fol et al., 2016; Hick et al., 2015; Richter et al., 2018; Ring et al., 2007) using recombinant, viral, and genetic strategies, suggesting a "plasticity-promoting" role of APP via the nonamyloidogenic processing pathway (Mockett et al., 2017). Based on these observations, we assumed that another major form of synaptic plasticity [i.e., homeostatic synaptic plasticity 
(Turrigiano et al., 1998)], could also depend on APP or one of its diverse processing products. Indeed, $A P P^{-/}$neurons failed to scale their synapses after TTX treatment, implicating APP in homeostatic plasticity, but APPs $\alpha$ could not rescue this APP-dependent plasticity phenotype. Similarly, scavenging endogenous APPs $\alpha$ or treatment with recombinant APPs $\alpha$ did not affect TTX-induced homeostatic synaptic plasticity in wild-type dentate granule cells. This phenomenon cannot be trivially explained by an inability of dentate granule cells to respond to APPs $\alpha$ because the exogenous application of APPs $\alpha$ robustly enhances LTP in these neurons (Taylor et al., 2008). Together, these observations suggest that the plasticitypromoting effect of APPs $\alpha$ (Mockett et al., 2017) should be narrowed down and specified: APP processing via the non-amyloidogenic pathway promotes the ability of neurons to express LTP, but not necessarily all forms of synaptic plasticity because our data demonstrates that APPs $\alpha$ is not a key regulator of homeostatic synaptic plasticity.

The inability to rescue homeostatic plasticity via APPs $\alpha$ raised the intriguing possibility that APP processing via the "amyloidogenic pathway" could serve homeostatic synaptic plasticity. In the presence of $A \beta$, the homeostatic synaptic response to TTX was fully restored in $\mathrm{APP}^{-/-}$preparations. Moreover, we report that pharmacologic inhibition of $\beta$-secretases blocks TTX-induced homeostatic synaptic plasticity in wild-type cultures. Because pharmacologic inhibition of $\gamma$-secretase had a similar effect, and $A \beta$ rescued homeostatic synaptic plasticity in the presence of $\beta$ - or $\gamma$-secretase inhibitors, other APP cleavage products [e.g., APPs $\beta$ (or additional factors arising from $\beta$ - or $\gamma$-secretase processing)] are unlikely to account for our significant findings. In a previous study, however, pharmacologic inhibition of $\gamma$-secretases did not block TTX-induced homeostatic synaptic plasticity (Pratt et al., 2011). These earlier experiments were carried out in primary hippocampal neurons rather than in organotypic tissue cultures, and L685,458 $(5 \mu \mathrm{M})$ was used instead to Begacestat $(1 \mu \mathrm{M})$ in our study. These differences may explain the inconsistent results. Notably, we confirmed that 
pharmacologic inhibition of $\gamma$-secretase with Begacestat reduced endogenous $A \beta$ levels in our experimental setting, and exogenous $A \beta_{1-42}$ rescued homeostatic synaptic plasticity in Begacestat-treated tissue cultures.

To provide further evidence for the role of $A \beta$ in neuronal physiology, we employed antibodies against $A \beta$ and scavenged endogenously produced $A \beta$ from wild-type tissue cultures. This approach abolished homeostatic synaptic scaling in the wild-type cultures and prevented synaptic scaling in $A P P^{-/}$preparations cultured together with $A P P^{+/+}$tissue; whereas a specific antibody against APPs $\alpha$ did not affect TTX-induced synaptic scaling. Together, we propose a model in which APP processing via the non-amyloidogenic pathway and the amyloidogenic pathway influences the ability of a neuron to express distinct forms of synaptic plasticity: processing along the non-amyloidogenic pathway may promote Hebbian plasticity (e.g., LTP), whereas processing along the amyloidogenic pathway-or increased availability of $A \beta$ (Gilbert et al., 2016)—promotes homeostatic synaptic plasticity (Figure 9).

What are the downstream pathways activated by $\mathrm{A} \beta$ in the context of homeostatic plasticity? Consistent with previous work on Hebbian plasticity (Gu et al., 2009; Sinnen et al., 2016; Snyder et al., 2005; Zhang et al., 2009; Zhao et al., 2004), we could link the homeostatic plasticity effects of $\mathrm{A} \beta$ to NMDA-Rs and CamKII. Considering the opposing roles of NMDA-R and CamKII in Hebbian and homeostatic synaptic plasticity, we speculated that $\mathrm{A} \beta$-signaling could be part of a $\mathrm{Ca}^{2+}$-dependent negative feedback mechanism that mediates homeostasis. Indeed, pharmacologic inhibition of NMDA-Rs and CamKII rescued homeostatic synaptic plasticity in $A P P^{-/-}$preparations, suggesting that $\mathrm{A} \beta$ acts on intracellular $\mathrm{Ca}^{2+}$ sensors or effectors, which responded to the TTX-induced reduction in intracellular $\mathrm{Ca}^{2+}$ in our experiments. Consistent with this suggestion, the previously reported $\mathrm{Ca}^{2+}$-dependent compensatory adjustment of synaptopodin was not observed in $A P P^{-/}$preparations [c.f., (Vlachos et al., 2013)], and interventions that rescued TTX-induced synaptic scaling in $A P P^{-/}$ 
dentate granule cells also triggered compensatory changes in synaptopodin. Moreover, A $\beta$ was not able to rescue homeostatic synaptic plasticity in $S Y N P O^{-/-}$preparations, demonstrating that synaptopodin is an essential downstream target through which APP/A $\beta$ asserts its effects on homeostatic synaptic plasticity.

In previous work, we have shown that the plasticity-related protein synaptopodin controls the ability of neurons to express both Hebbian and homeostatic synaptic plasticity (Deller et al., 2003; Jedlicka et al., 2009; Vlachos et al., 2013; Vlachos et al., 2009). Animals lacking this protein do not form spine apparatus organelles and exhibit deficits in Hebbian and homeostatic synaptic plasticity (Deller et al., 2003; Jedlicka et al., 2009; Vlachos et al., 2013) because the $\mathrm{Ca}^{2+}$-dependent accumulation of AMPA-Rs at excitatory postsynapses is impaired [e.g., (Maggio and Vlachos, 2018; Vlachos et al., 2013; Vlachos et al., 2009)]. The results of the present study call for a systematic assessment of the activity-dependent molecular pathways through which APP processing via the "amyloidogenic/homeostatic"" and "non-amyloidogenic/Hebbian plasticity promoting" pathways affect synaptopodinmediated synaptic plasticity. It may be important to mention in this context that changes in synaptopodin expression have been reported in brain tissue from AD subjects (Reddy et al., 2005) and synaptopodin has been recently linked to autophagy of phospho-MAPT/Tau (Ji et al., 2019). Moreover, a reduction in synaptopodin expression seems to ameliorate symptoms in a transgenic mouse model of AD (Aloni et al., 2019).

A role of homeostatic synaptic plasticity in AD has been recently discussed (Jang and Chung, 2016; Styr and Slutsky, 2018). In the context of our data, which suggest a physiological role of $A \beta$, it can be speculated that the previously reported "synaptotoxic" effects of A $\beta$ [e.g., (Mucke and Selkoe, 2012; Westmark, 2013; Zott et al., 2019)] are the result of a pathological over-activation of molecular machinery promoting synaptic homeostasis under physiological conditions. Consistent with this pathophysiological concept, $\mathrm{A} \beta$ mediated "alterations" in LTP in AD models might reflect -at least in part- enhanced 
408 homeostatic synaptic plasticity, which rapidly returns potentiated synapses to baseline upon 409 LTP induction. Clearly, the biological consequences of the "amyloidogenic/homeostatic" and 410 the "non-amyloidogenic/Hebbian plasticity promoting" pathways warrant further

411 investigation in the AD context, particularly because the amyloidogenic pathway is an

412 important target for therapeutic intervention in AD (Coimbra et al., 2018; Egan et al., 2019;

413 Yan and Vassar, 2014). Hence, some of the side-effects observed in patients treated with $\beta$ -

414 secretase inhibitors (Coimbra et al., 2018; Egan et al., 2019) may have been caused by

415 interference with the ability of healthy neurons to express homeostatic synaptic plasticity. 


\section{MATERIALS AND METHODS}

Ethics statement. Mice were maintained in a $12 \mathrm{~h}$ light/dark cycle with food and water available ad libitum. Every effort was made to minimize distress and pain of animals. All experimental procedures were performed according to German animal welfare legislation and approved by the appropriate animal welfare committee and the animal welfare officer of Freiburg University.

Animals. Wild-type C57BL/6J, SYNPO ${ }^{-/}$(Deller et al., 2003), $A P P^{-/}(\mathrm{Li}$ et al., 1996), $A P P s \alpha-$ KI mice (Ring et al., 2007) and their wild-type littermates were used in this study.

Preparation of tissue cultures. Enthorhino-hippocampal tissue cultures were prepared at postnatal day 4-5 from mice of either sex as previously described (Vlachos et al. 2012). The incubation medium consisted of $50 \%(\mathrm{v} / \mathrm{v})$ minimum essential medium (MEM), $25 \%(\mathrm{v} / \mathrm{v})$ basal medium eagle (BME), $25 \%(\mathrm{v} / \mathrm{v})$ heat inactivated normal horse serum (NHS), $25 \mathrm{mM}$ HEPES, $0.15 \%$ (w/v) $\mathrm{NaHCO}_{3}, 0.65 \%$ (w/v) Glucose, $0.1 \mathrm{mg} / \mathrm{ml}$ Streptomycin, $100 \mathrm{U} / \mathrm{ml}$ Penicillin and $2 \mathrm{mM}$ Glutamax. The $\mathrm{pH}$ was adjusted to 7.3 and the medium was changed 3 times per week. Tissue cultures were allowed to mature in vitro for at least 18 days before any experimental procedure.

Whole cell patch-clamp. Whole cell patch-clamp recordings of dentate gyrus granule cells were carried out at $35^{\circ} \mathrm{C}$. The bath solution contained $126 \mathrm{mM} \mathrm{NaCl}, 2.5 \mathrm{mM} \mathrm{KCl}, 26 \mathrm{mM}$ $\mathrm{NaHCO}_{3}, 1.25 \mathrm{mM} \mathrm{NaH} 2 \mathrm{PO}_{4}, 2 \mathrm{mM} \mathrm{CaCl}, 2 \mathrm{mM} \mathrm{MgCl}_{2}$ and $10 \mathrm{mM}$ glucose and was saturated with 95\% O2 / 5\% CO2. For miniature and spontaneous AMPA receptor mediated post synaptic current (m/sEPSC) recordings as well as current clamp (input-output) recordings patch pipettes contained $126 \mathrm{mM} \mathrm{K-gluconate,} 4 \mathrm{mM} \mathrm{KCl}, 4 \mathrm{mM}$ ATP-Mg, $0.3 \mathrm{mM}$ GTP$\mathrm{Na}_{2}, 10 \mathrm{mM}$ PO-Creatine, $10 \mathrm{mM}$ HEPES and 0.1\% Biocytin $(\mathrm{pH}=7.25$ with KOH, 290 
mOsm with sucrose). For NMDA receptor mediated mEPSC recordings patch pipettes contained $120 \mathrm{mM} \mathrm{CsCH}_{3} \mathrm{SO}_{3}, 8 \mathrm{mM} \mathrm{CsCl}, 1 \mathrm{mM} \mathrm{MgCl}$, $0.4 \mathrm{mM}$ EGTA, $2 \mathrm{mM}$ ATP-Mg, $0.3 \mathrm{mM}$ GTP-Na2, $10 \mathrm{mM}$ PO-Creatine, 10mM HEPES and $5 \mathrm{mM}$ QX-314 (pH = 7.25 with $\mathrm{CsOH}, 295$ mOsm with sucrose). For miniature and spontaneous inhibitory post synaptic current (m/sIPSC) recordings patch pipettes contained $40 \mathrm{mM} \mathrm{CsCl}, 90 \mathrm{mM} \mathrm{K}$-gluconate, 1.8 $\mathrm{mM} \mathrm{NaCl}, 1.7 \mathrm{mM} \mathrm{MgCl} 2,3.5 \mathrm{mM} \mathrm{KCl}, 0.05$ mM EGTA, 2 mM ATP-Mg, 0.4 mM GTPNa2, $10 \mathrm{mM}$ PO-Creatine, $10 \mathrm{mM}$ HEPES ( $\mathrm{pH}=7.25$ with $\mathrm{CsOH}, 270 \mathrm{mOsm}$ with sucrose). AMPA receptor - mediated mEPSCs were recorded in the presence of $10 \mu \mathrm{M}$ D-APV and 0.5 $\mu \mathrm{M}$ TTX, NMDA-R-mediated mEPSCs in the presence of $10 \mu \mathrm{M}$ CNQX and $0.5 \mu \mathrm{M}$ TTX and mIPSCs in the presence of $0.5 \mu \mathrm{M}$ TTX, $10 \mu \mathrm{M}$ D-APV and $10 \mu \mathrm{M}$ CNQX. sEPSCs were recorded without the addition of any drugs in the bath solution and sIPSCs in the presence of $10 \mu \mathrm{M}$ D-APV and $10 \mu \mathrm{M}$ CNQX. Current clamp recordings were performed in the presence of $10 \mu \mathrm{M}$ D-APV, $10 \mu \mathrm{M}$ CNQX and $10 \mu \mathrm{M}$ Bicuculline methiodide. Neurons were recorded at a holding potential of $-70 \mathrm{mV}$ for $\mathrm{m} / \mathrm{sIPSCs}$ and AMPA receptor mediated $\mathrm{m} / \mathrm{sEPSCs}$. NMDA receptor mediated mEPSCs were acquired at $+40 \mathrm{mV}$. For current clamp recordings neurons were hyperpolarized at $-100 \mathrm{pA}$ and then depolarized up to $+200 \mathrm{pA}$ with onesecond-long 10 pA current injection steps. Series resistance was monitored in 2 min intervals, and recordings were discarded if the series resistance reached $\geq 30 \mathrm{M} \Omega$ and the leak current changed significantly.

Reconstruction of dendritic trees and spine density analysis. Dentate granule cells were patched with Alexa $568(10 \mu \mathrm{M})$ added to the internal solution and filled for 10 minutes in whole-cell configuration for visualization of identified cells. Confocal image stacks of granule cells $(512 \times 512$ pixel, voxel size $0.49 \times 0.49 \times 2 \mu \mathrm{m})$ were acquired directly at the electrophysiology setup using a Zeiss LSM Exciter confocal microscope with a 40x water immersion objective lens ( $0.8 \mathrm{NA}$; Zeiss). Granule cells were manually reconstructed in 3D 
and analyzed using Neurolucida/NeuroExplorer software (MBF Bioscience). Total dendritic length (TDL) was calculated as the sum of length of all reconstructed dendritic segments of a given cell. For Sholl analysis, concentric spheres with diameters increasing in $20 \mu \mathrm{m}$ increments were drawn around the cell soma, and the number of dendrites intersecting each sphere was calculated. Outer molecular layer (OML) segments were imaged with higher scan zoom and spine densities were determined as described previously (Hick et al., 2015).

Immunostaining and imaging. Tissue cultures were fixed in a solution of $4 \%(\mathrm{w} / \mathrm{v})$ paraformaldehyde (PFA) and $4 \%(\mathrm{w} / \mathrm{v})$ sucrose in $0.01 \mathrm{M}$ phosphate-buffered saline (PBS) for $1 \mathrm{~h}$, followed by $2 \%(\mathrm{w} / \mathrm{v})$ PFA and $30 \%$ (w/v) sucrose in $0.01 \mathrm{M}$ PBS overnight. For synaptopodin staining. $30 \mu \mathrm{m}$ cryo-sections were prepared, and stained with antibodies against synaptopodin (1:1000; SE-19 Sigma-Aldrich, RRID: AB_261570). Sections were incubated for $1 \mathrm{~h}$ with $10 \%$ (v/v) normal goat serum (NGS) in $0.5 \%(\mathrm{v} / \mathrm{v})$ Triton X-100containing PBS to reduce unspecific antibody binding and incubated for $24 \mathrm{~h}$ at $4{ }^{\circ} \mathrm{C}$ with the primary antibody in PBS with $10 \%$ NGS and $0.1 \%$ Triton X-100. Sections were washed and incubated for $4 \mathrm{~h}$ with appropriate Alexa- labelled secondary antibodies (Invitrogen; 1:1000, in PBS with $10 \%$ NGS, $0.1 \%$ Triton X-100). DAPI nuclear stain was used to visualize cytoarchitecture (1:5000; in 0.01 M PBS for $15 \mathrm{~min}$ ). Sections were washed with $0.1 \mathrm{M}$ PBS, transferred onto glass slides and mounted for visualization with anti-fading mounting medium. Confocal images were acquired using a Leica TCS SP8 laser scanning microscope with 20x (NA 0.75; Leica), 40x (NA 1.30; Leica) and 63x (NA 1.40; Leica) oil-submersion objectives.

Post-hoc identification of recorded neurons. Tissue cultures were fixed in a solution of $4 \%$ $(\mathrm{w} / \mathrm{v})$ and $4 \%(\mathrm{w} / \mathrm{v})$ sucrose in $0.01 \mathrm{M}$ PBS for $1 \mathrm{~h}$. The fixed tissue was incubated for $1 \mathrm{~h}$ with $10 \%$ (v/v) NGS and $0.5 \%$ (v/v) Triton X-100 in 0.01 M PBS. Biocytin (Sigma-Aldrich 
Cat\# B4261) filled cells were stained with Alexa-488, -568 or -633 conjugated Streptavidin (Thermo Fisher Scientific; 1:1000; in 0.01 M PBS with $10 \%$ NGS and $0.1 \%$ Triton X100) for $4 \mathrm{~h}$ and DAPI (Thermo Fisher Scientific) staining was used to visualize cytoarchitecture (1:5000; in 0.01 M PBS for $15 \mathrm{~min}$ ). Slices were washed, transferred and mounted onto glass slides for visualization. Virus expressing and streptavidin stained granule cells were visualized with a Leica TCS SP8 laser scanning microscope with 20x (NA 0.75; Leica), 40x (NA 1.30; Leica) and 63x (NA 1.40; Leica) oil-submersion objectives.

Electron microscopy. Tissue cultures were fixed and prepared as described previously (Vlachos et al., 2013). Briefly, cultures were fixed in 15\% picric acid, $4 \%$ glutaraldehyd, $4 \%$ PFA in PB-buffer. After washing in $\mathrm{PB}$, cultures were osmicated $\left(0.5 \% \mathrm{OsO}_{4}\right.$ in $\mathrm{PB}, 30$ minutes), dehydrated (70\% ethanol containing 1\% uranyl acetate), and embedded between liquid release-coated slides and coverslips. Cultures were re-embedded in blocks and serial ultrathin sections were collected on single-slot Formvar-coated copper grids. Ultrathin sections were examined in a Zeiss electron microscope (EM 109).

Pharmacology. Tissue cultures were treated with tetrodotoxin (TTX ; $2 \mu \mathrm{M}$; BioTrend, Cat\# BN0518), D-APV (50 $\mu \mathrm{M}$; Tocris, Cat\# 0106) synthetic $\mathrm{A} \beta_{1-42}(1.5 \mu \mathrm{M}$; Bachem, Cat\# 4014447) or $\mathrm{A} \beta_{42-1}(1.5 \mu \mathrm{M}$; Bachem, Cat\# H-3976) (Novotny et al., 2016), recombinant APPs $\alpha$ (10 nM) (Hick et al., 2015), BACE inhibitor C3 (20 $\mu \mathrm{M}$; Calbiochem, Sigma-Aldrich Cat\# 565788), Begacestat ( $1 \mu \mathrm{M}$; Tocris, Cat\# 4283), KN-92 (5 $\mu \mathrm{M}$; Tocris, Cat\# 4130), KN93 (5 $\mu \mathrm{M}$; Tocris, Cat\# 1278), BNT77 (1.3 $\mu \mathrm{g} / \mathrm{ml}$; Wako, Cat\# 014-26881, RRID: AB_2827702), JRD32 [1.3 $\mu \mathrm{g} / \mathrm{ml}$; (Hick et al., 2015), RRID: AB_2827703] for 2 days. For the $A \beta$ treatment, PBS was added to the lyophilized $A \beta$ peptides, followed by $3 \times 1$ min vortexing on wet ice and stocks were kept at $-80^{\circ} \mathrm{C}$. Before treating the tissue cultures, $A \beta_{1-42}$ and $A \beta_{42-1}$ were slowly thawed in ice and vortexed again before adding in the medium. 
Viral transduction. Tissue cultures were transfected between 3-4 div by adding $1 \mu 1$ of AAV-Syn/Venus_T2A_APPs $\alpha(A A V-A P P s \alpha)$ or $1 \mu$ of AAV-Syn/APP695_T2A_Venus (AAV-flAPP-Venus; kindly provided by Drs. Christian Buchholz and Tobias Abel) directly on top of each culture. Tissue cultures were then left to mature at least until 18 div before experimental assessment.

ELISA assay and A $\boldsymbol{\beta}$ peptide quantification. Incubation medium from vehicle-only(control) and pharmacologically-treated 3-week-old tissue cultures was collected, frozen immediately with dry ice, and stored at $-80^{\circ} \mathrm{C}$ (vehicle, $\mathrm{n}=6$ wells with 36 tissue cultures; BACE inhibitor C3, $\mathrm{n}=3$ wells with 18 tissue cultures; Begacestat, $\mathrm{n}=3$ wells with 18 tissue cultures). For the detection of $A \beta_{1-42}$ a V-PLEX ${ }^{\mathrm{TM}} \mathrm{A} \beta$ Peptide Panel 1 Kit (MesoScale Discovery, Rockville, USA, Cat\# K15199E, RRID: AB_2827747) was used with a ruthenylated anti-A $\beta$ antibody (4G8 clone). The $A \beta$ peptide concentration was determined using the MSD Discovery Workbench software (MesoScale Discovery, Rockville, USA).

Quantification and statistics. Analyses were performed with the person analyzing the data blind to experimental condition. One to two tissue cultures were used from each animal. Electrophysiological data were analyzed using pClamp 10.7 software suite (Molecular Devices), MiniAnalysis (Synaptosoft) and Igor Pro 7 (Wavemetrics). 150-300 events were analyzed per recorded neuron. Sizes of immunolabelled synaptopodin clusters were assessed using the FIJI - ImageJ software package (available from https://imagej.net/ImageJ) as described previously (Vlachos et al., 2013). Statistical comparisons were made using MannWhitney test (to compare two groups), Kruskal-Wallis-test followed by Dunn's post-hoc test for multiple group testing or one or two-way ANOVA as indicated in the figure captions and text (GraphPad Prism 7, GraphPad software, USA). P-values of less than 0.05 were 
534 considered a significant difference. All values represent mean \pm standard error of the mean. In

535 the figures $*$ denotes $\mathrm{p}<0.05, * * \mathrm{p}<0.01$ and $* * * \mathrm{p}<0.001$; no significant differences are 536 indicated with 'NS'.

537 Digital illustrations. Confocal image stacks were exported as 2D-projections and stored as 538 TIF files. Figures were prepared using Photoshop graphics software (Adobe, San Jose, CA, 539 USA). Image brightness and contrast were adjusted. 


\section{ACKNOWLEDGEMENTS}

We thank Anke Biczysko, Sussana Glaser, Katrin Moschke, and Barbara Joch for excellent technical assistance. We also thank Drs. Christian Buchholz and Tobias Abel for providing AAV vectors. The work was supported by the Federal Ministry of Education and Research, Germany (BMBF 'OGEAM' to T.D and U.M.), under Germany's Excellence Strategy within

544 the framework of the Munich Cluster for Systems Neurology (EXC 2145 SyNergy- ID 545 390857198, to SFL) and by Deutsche Forschungsgemeinschaft (MU1457/14-1 to U.M., FOR 1332 to U.M., T.D., A.V., CRC1080 T.D. and A.V., and CRC 974. to A.V.).

\section{AUTHOR CONTRIBUTIONS}

547 The study was conceived and supervised by AV. Experiments were designed by CG, UM, TD 548 and AV. CG, MF and DB performed experiments and analyzed the data. Sandwich-ELISA 549 experiments were supervised by SFL. CB and UM provided recombinant APPs $\alpha$, anti-APPs $\alpha$ 550 antibodies, $\mathrm{APP}^{-/-}$and APPs $\alpha-\mathrm{KI}$ mice. The manuscript was written by AV with the help of 551 CG, SFL, UM and TD. All authors were involved in data interpretation and critically revising 552 the manuscript.

\section{DECLARATION OF INTERESTS}

553 The authors declare no competing financial interests. 


\section{REFERENCES}

Aimone, J.B., Deng, W., and Gage, F.H. (2011). Resolving new memories: a critical look at the dentate gyrus, adult neurogenesis, and pattern separation. Neuron 70, 589-596. Aloni, E., Oni-Biton, E., Tsoory, M., Moallem, D.H., and Segal, M. (2019). Synaptopodin Deficiency Ameliorates Symptoms in the 3xTg Mouse Model of Alzheimer's Disease. J Neurosci 39, 3983-3992.

Andre, E.A., Forcelli, P.A., and Pak, D.T. (2018). What goes up must come down: homeostatic synaptic plasticity strategies in neurological disease. Future Neurol 13, 13-21.

Barao, S., Moechars, D., Lichtenthaler, S.F., and De Strooper, B. (2016). BACE1 Physiological Functions May Limit Its Use as Therapeutic Target for Alzheimer's Disease. Trends Neurosci 39, 158-169.

Bohm, C., Chen, F., Sevalle, J., Qamar, S., Dodd, R., Li, Y., Schmitt-Ulms, G., Fraser, P.E., and St George-Hyslop, P.H. (2015). Current and future implications of basic and translational research on amyloid-beta peptide production and removal pathways. Mol Cell Neurosci 66, 311.

Chen, Q.S., Wei, W.Z., Shimahara, T., and Xie, C.W. (2002). Alzheimer amyloid betapeptide inhibits the late phase of long-term potentiation through calcineurin-dependent mechanisms in the hippocampal dentate gyrus. Neurobiol Learn Mem 77, 354-371.

Chow, V.W., Mattson, M.P., Wong, P.C., and Gleichmann, M. (2010). An overview of APP processing enzymes and products. Neuromolecular Med 12, 1-12.

Cingolani, L.A., Thalhammer, A., Lily, M., Catalano, M., Ramos, T., Colicos, M.A., and Goda, Y. (2008). Activity-dependent regulation of synaptic AMPA receptor composition and abundance by $\beta 3$ integrins. Neuron 58, 749-762.

Cirrito, J.R., May, P.C., O'Dell, M.A., Taylor, J.W., Parsadanian, M., Cramer, J.W., Audia, J.E., Nissen, J.S., Bales, K.R., Paul, S.M., et al. (2003). In vivo assessment of brain interstitial fluid with microdialysis reveals plaque-associated changes in amyloid-beta metabolism and half-life. J Neurosci 23, 8844-8853.

Coimbra, J.R.M., Marques, D.F.F., Baptista, S.J., Pereira, C.M.F., Moreira, P.I., Dinis, T.C.P., Santos, A.E., and Salvador, J.A.R. (2018). Highlights in BACE1 Inhibitors for Alzheimer's Disease Treatment. Front Chem 6, 178.

Dawson, G.R., Seabrook, G.R., Zheng, H., Smith, D.W., Graham, S., O'Dowd, G., Bowery, B.J., Boyce, S., Trumbauer, M.E., Chen, H.Y., et al. (1999). Age-related cognitive deficits, impaired long-term potentiation and reduction in synaptic marker density in mice lacking the beta-amyloid precursor protein. Neuroscience 90, 1-13.

Deller, T., and Frotscher, M. (1997). Lesion-induced plasticity of central neurons: sprouting of single fibres in the rat hippocampus after unilateral entorhinal cortex lesion. Prog Neurobiol 53, 687-727.

Deller, T., Korte, M., Chabanis, S., Drakew, A., Schwegler, H., Stefani, G.G., Zuniga, A., Schwarz, K., Bonhoeffer, T., Zeller, R., et al. (2003). Synaptopodin-deficient mice lack a spine apparatus and show deficits in synaptic plasticity. Proc Natl Acad Sci U S A 100, 10494-10499.

Echegoyen, J., Neu, A., Graber, K.D., and Soltesz, I. (2007). Homeostatic plasticity studied using in vivo hippocampal activity-blockade: synaptic scaling, intrinsic plasticity and agedependence. PloS one 2, e700.

Egan, M.F., Kost, J., Voss, T., Mukai, Y., Aisen, P.S., Cummings, J.L., Tariot, P.N., Vellas, B., van Dyck, C.H., Boada, M., et al. (2019). Randomized Trial of Verubecestat for Prodromal Alzheimer's Disease. N Engl J Med 380, 1408-1420.

Fol, R., Braudeau, J., Ludewig, S., Abel, T., Weyer, S.W., Roederer, J.-P., Brod, F., Audrain, M., Bemelmans, A.-P., Buchholz, C.J., et al. (2016). Viral gene transfer of APPs $\alpha$ rescues 
synaptic failure in an Alzheimer's disease mouse model. Acta Neuropathologica 131, 247266.

Friedman, H.R., and Goldman-Rakic, P.S. (1988). Activation of the hippocampus and dentate gyrus by working-memory: a 2-deoxyglucose study of behaving rhesus monkeys. J Neurosci 8, 4693-4706.

Gilbert, J., Shu, S., Yang, X., Lu, Y., Zhu, L.Q., and Man, H.Y. (2016). beta-Amyloid triggers aberrant over-scaling of homeostatic synaptic plasticity. Acta Neuropathol Commun 4, 131. Goddard, C.A., Butts, D.A., and Shatz, C.J. (2007). Regulation of CNS synapses by neuronal MHC class I. Proc Natl Acad Sci U S A 104, 6828-6833.

Gu, Z., Liu, W., and Yan, Z. (2009). \{beta\}-Amyloid impairs AMPA receptor trafficking and function by reducing $\mathrm{Ca} 2+/$ calmodulin-dependent protein kinase II synaptic distribution. $\mathrm{J}$ Biol Chem 284, 10639-10649.

Hashimoto, M., Bogdanovic, N., Volkmann, I., Aoki, M., Winblad, B., and Tjernberg, L.O. (2010). Analysis of microdissected human neurons by a sensitive ELISA reveals a correlation between elevated intracellular concentrations of Abeta42 and Alzheimer's disease neuropathology. Acta Neuropathol 119, 543-554.

Herms, J., Anliker, B., Heber, S., Ring, S., Fuhrmann, M., Kretzschmar, H., Sisodia, S., and Muller, U. (2004). Cortical dysplasia resembling human type 2 lissencephaly in mice lacking all three APP family members. EMBO J 23, 4106-4115.

Hick, M., Herrmann, U., Weyer, S.W., Mallm, J.P., Tschape, J.A., Borgers, M., Mercken, M., Roth, F.C., Draguhn, A., Slomianka, L., et al. (2015). Acute function of secreted amyloid precursor protein fragment APPsalpha in synaptic plasticity. Acta Neuropathol 129, 21-37.

Hoe, H.S., Lee, H.K., and Pak, D.T. (2012). The upside of APP at synapses. CNS Neurosci Ther 18, 47-56.

Jang, S.S., and Chung, H.J. (2016). Emerging Link between Alzheimer's Disease and Homeostatic Synaptic Plasticity. Neural Plast 2016, 7969272.

Jedlicka, P., Schwarzacher, S.W., Winkels, R., Kienzler, F., Frotscher, M., Bramham, C.R., Schultz, C., Bas Orth, C., and Deller, T. (2009). Impairment of in vivo theta-burst long-term potentiation and network excitability in the dentate gyrus of synaptopodin-deficient mice lacking the spine apparatus and the cisternal organelle. Hippocampus 19, 130-140.

Ji, C., Tang, M., Zeidler, C., Hohfeld, J., and Johnson, G.V. (2019). BAG3 and SYNPO (synaptopodin) facilitate phospho-MAPT/Tau degradation via autophagy in neuronal processes. Autophagy 15, 1199-1213.

Kim, J., and Tsien, R.W. (2008). Synapse-specific adaptations to inactivity in hippocampal circuits achieve homeostatic gain control while dampening network reverberation. Neuron 58 , 925-937.

Konietzny, A., Gonzalez-Gallego, J., Bar, J., Perez-Alvarez, A., Drakew, A., Demmers, J.A.A., Dekkers, D.H.W., Hammer, J.A., 3rd, Frotscher, M., Oertner, T.G., et al. (2019). Myosin V regulates synaptopodin clustering and localization in the dendrites of hippocampal neurons. J Cell Sci 132, jcs230177.

Lenz, M., Galanis, C., Kleidonas, D., Fellenz, M., Deller, T., and Vlachos, A. (2019). Denervated mouse dentate granule cells adjust their excitatory but not inhibitory synapses following in vitro entorhinal cortex lesion. Exp Neurol 312, 1-9.

Li, Z.W., Stark, G., Gotz, J., Rulicke, T., Gschwind, M., Huber, G., Muller, U., and Weissmann, C. (1996). Generation of mice with a 200-kb amyloid precursor protein gene deletion by Cre recombinase-mediated site-specific recombination in embryonic stem cells. Proc Natl Acad Sci U S A 93, 6158-6162.

Lichtenthaler, S.F., Haass, C., and Steiner, H. (2011). Regulated intramembrane proteolysis-lessons from amyloid precursor protein processing. J Neurochem 117, 779-796. 
Lisman, J. (2017). Glutamatergic synapses are structurally and biochemically complex because of multiple plasticity processes: long-term potentiation, long-term depression, shortterm potentiation and scaling. Philos Trans R Soc Lond B Biol Sci 372.

Ludewig, S., and Korte, M. (2016). Novel Insights into the Physiological Function of the APP (Gene) Family and Its Proteolytic Fragments in Synaptic Plasticity. Front Mol Neurosci 9, 161.

Magara, F., Muller, U., Li, Z.W., Lipp, H.P., Weissmann, C., Stagljar, M., and Wolfer, D.P. (1999). Genetic background changes the pattern of forebrain commissure defects in transgenic mice underexpressing the beta-amyloid-precursor protein. Proc Natl Acad Sci U S A 96, 4656-4661.

Maggio, N., and Vlachos, A. (2018). Tumor necrosis factor (TNF) modulates synaptic plasticity in a concentration-dependent manner through intracellular calcium stores. $\mathrm{J}$ Mol Med (Berl) 96, 1039-1047.

Martone, R.L., Zhou, H., Atchison, K., Comery, T., Xu, J.Z., Huang, X., Gong, X., Jin, M., Kreft, A., Harrison, B., et al. (2009). Begacestat (GSI-953): a novel, selective thiophene sulfonamide inhibitor of amyloid precursor protein gamma-secretase for the treatment of Alzheimer's disease. J Pharmacol Exp Ther 331, 598-608.

Mockett, B.G., Richter, M., Abraham, W.C., and Muller, U.C. (2017). Therapeutic Potential of Secreted Amyloid Precursor Protein APPsalpha. Front Mol Neurosci 10, 30.

Mucke, L., and Selkoe, D.J. (2012). Neurotoxicity of amyloid beta-protein: synaptic and network dysfunction. Cold Spring Harb Perspect Med 2, a006338.

Muller, U., Cristina, N., Li, Z.W., Wolfer, D.P., Lipp, H.P., Rulicke, T., Brandner, S., Aguzzi, A., and Weissmann, C. (1994). Behavioral and anatomical deficits in mice homozygous for a modified beta-amyloid precursor protein gene. Cell 79, 755-765.

Müller, U.C., Deller, T., and Korte, M. (2017). Not just amyloid: physiological functions of the amyloid precursor protein family. Nature Reviews Neuroscience 18, 281.

Novotny, R., Langer, F., Mahler, J., Skodras, A., Vlachos, A., Wegenast-Braun, B.M., Kaeser, S.A., Neher, J.J., Eisele, Y.S., Pietrowski, M.J., et al. (2016). Conversion of Synthetic Abeta to In Vivo Active Seeds and Amyloid Plaque Formation in a Hippocampal Slice Culture Model. J Neurosci 36, 5084-5093.

Opazo, P., Viana da Silva, S., Carta, M., Breillat, C., Coultrap, S.J., Grillo-Bosch, D., Sainlos, M., Coussen, F., Bayer, K.U., Mulle, C., and Choquet, D. (2018). CaMKII Metaplasticity Drives Abeta Oligomer-Mediated Synaptotoxicity. Cell Rep 23, 3137-3145.

Pratt, K.G., Zimmerman, E.C., Cook, D.G., and Sullivan, J.M. (2011). Presenilin 1 regulates homeostatic synaptic scaling through Akt signaling. Nat Neurosci 14, 1112-1114.

Reddy, P.H., Mani, G., Park, B.S., Jacques, J., Murdoch, G., Whetsell, W., Jr., Kaye, J., and Manczak, M. (2005). Differential loss of synaptic proteins in Alzheimer's disease: implications for synaptic dysfunction. J Alzheimers Dis 7, 103-117; discussion 173-180.

Richter, M.C., Ludewig, S., Winschel, A., Abel, T., Bold, C., Salzburger, L.R., Klein, S., Han, K., Weyer, S.W., Fritz, A.K., et al. (2018). Distinct in vivo roles of secreted APP ectodomain variants APPsalpha and APPsbeta in regulation of spine density, synaptic plasticity, and cognition. EMBO J 37, e98335.

Ring, S., Weyer, S.W., Kilian, S.B., Waldron, E., Pietrzik, C.U., Filippov, M.A., Herms, J., Buchholz, C., Eckman, C.B., Korte, M., et al. (2007). The secreted beta-amyloid precursor protein ectodomain APPs alpha is sufficient to rescue the anatomical, behavioral, and electrophysiological abnormalities of APP-deficient mice. J Neurosci 27, 7817-7826.

Seabrook, G.R., Smith, D.W., Bowery, B.J., Easter, A., Reynolds, T., Fitzjohn, S.M., Morton, R.A., Zheng, H., Dawson, G.R., Sirinathsinghji, D.J., et al. (1999). Mechanisms contributing to the deficits in hippocampal synaptic plasticity in mice lacking amyloid precursor protein. Neuropharmacology 38, 349-359. 
Seubert, P., Vigo-Pelfrey, C., Esch, F., Lee, M., Dovey, H., Davis, D., Sinha, S., Schlossmacher, M., Whaley, J., Swindlehurst, C., and et al. (1992). Isolation and quantification of soluble Alzheimer's beta-peptide from biological fluids. Nature 359, 325327.

Shoji, M., Golde, T.E., Ghiso, J., Cheung, T.T., Estus, S., Shaffer, L.M., Cai, X.D., McKay, D.M., Tintner, R., Frangione, B., and et al. (1992). Production of the Alzheimer amyloid beta protein by normal proteolytic processing. Science 258, 126-129.

Sinnen, B.L., Bowen, A.B., Gibson, E.S., and Kennedy, M.J. (2016). Local and UseDependent Effects of beta-Amyloid Oligomers on NMDA Receptor Function Revealed by Optical Quantal Analysis. J Neurosci 36, 11532-11543. Smith-Dijak, A.I., Nassrallah, W.B., Zhang, L.Y.J., Geva, M., Hayden, M.R., and Raymond, L.A. (2019). Impairment and Restoration of Homeostatic Plasticity in Cultured Cortical Neurons From a Mouse Model of Huntington Disease. Front Cell Neurosci 13, 209. Snyder, E.M., Nong, Y., Almeida, C.G., Paul, S., Moran, T., Choi, E.Y., Nairn, A.C., Salter, M.W., Lombroso, P.J., Gouras, G.K., and Greengard, P. (2005). Regulation of NMDA receptor trafficking by amyloid-beta. Nat Neurosci 8, 1051-1058.

Stachel, S.J., Coburn, C.A., Steele, T.G., Jones, K.G., Loutzenhiser, E.F., Gregro, A.R., Rajapakse, H.A., Lai, M.T., Crouthamel, M.C., Xu, M., et al. (2004). Structure-based design of potent and selective cell-permeable inhibitors of human beta-secretase (BACE-1). J Med Chem 47, 6447-6450.

Stellwagen, D., and Malenka, R.C. (2006). Synaptic scaling mediated by glial TNF-alpha. Nature 440, 1054-1059.

Steward, O. (1994). Cholinergic sprouting is blocked by repeated induction of electroconvulsive seizures, a manipulation that induces a persistent reactive state in astrocytes. Exp Neurol 129, 103-111.

Strehl, A., Galanis, C., Radic, T., Schwarzacher, S.W., Deller, T., and Vlachos, A. (2018). Dopamine Modulates Homeostatic Excitatory Synaptic Plasticity of Immature Dentate Granule Cells in Entorhino-Hippocampal Slice Cultures. Front Mol Neurosci 11, 303.

Styr, B., and Slutsky, I. (2018). Imbalance between firing homeostasis and synaptic plasticity drives early-phase Alzheimer's disease. Nat Neurosci 21, 463-473.

Sun, Q., and Turrigiano, G.G. (2011). PSD-95 and PSD-93 play critical but distinct roles in synaptic scaling up and down. J Neurosci 31, 6800-6808.

Sutton, M.A., Ito, H.T., Cressy, P., Kempf, C., Woo, J.C., and Schuman, E.M. (2006). Miniature neurotransmission stabilizes synaptic function via tonic suppression of local dendritic protein synthesis. Cell 125, 785-799.

Tan, V.T.Y., Mockett, B.G., Ohline, S.M., Parfitt, K.D., Wicky, H.E., Peppercorn, K., Schoderboeck, L., Yahaya, M.F.B., Tate, W.P., Hughes, S.M., and Abraham, W.C. (2018). Lentivirus-mediated expression of human secreted amyloid precursor protein-alpha prevents development of memory and plasticity deficits in a mouse model of Alzheimer's disease. Mol Brain 11, 7 .

Taylor, C.J., Ireland, D.R., Ballagh, I., Bourne, K., Marechal, N.M., Turner, P.R., Bilkey, D.K., Tate, W.P., and Abraham, W.C. (2008). Endogenous secreted amyloid precursor protein-alpha regulates hippocampal NMDA receptor function, long-term potentiation and spatial memory. Neurobiol Dis 31, 250-260.

Townsend, M., Mehta, T., and Selkoe, D.J. (2007). Soluble Abeta inhibits specific signal transduction cascades common to the insulin receptor pathway. J Biol Chem 282, 3330533312 .

Turrigiano, G.G. (1999). Homeostatic plasticity in neuronal networks: the more things change, the more they stay the same. Trends in Neurosciences 22, 221-227.

Turrigiano, G.G. (2008). The self-tuning neuron: synaptic scaling of excitatory synapses. Cell $135,422-435$. 
Turrigiano, G.G., Leslie, K.R., Desai, N.S., Rutherford, L.C., and Nelson, S.B. (1998). Activity-dependent scaling of quantal amplitude in neocortical neurons. Nature 391, 892-896. Tyan, S.H., Shih, A.Y., Walsh, J.J., Maruyama, H., Sarsoza, F., Ku, L., Eggert, S., Hof, P.R., Koo, E.H., and Dickstein, D.L. (2012). Amyloid precursor protein (APP) regulates synaptic structure and function. Mol Cell Neurosci 51, 43-52.

Vlachos, A., Becker, D., Jedlicka, P., Winkels, R., Roeper, J., and Deller, T. (2012). Entorhinal denervation induces homeostatic synaptic scaling of excitatory postsynapses of dentate granule cells in mouse organotypic slice cultures. PLoS One 7, e32883.

Vlachos, A., Ikenberg, B., Lenz, M., Becker, D., Reifenberg, K., Bas-Orth, C., and Deller, T. (2013). Synaptopodin regulates denervation-induced homeostatic synaptic plasticity. Proc Natl Acad Sci U S A 110, 8242-8247.

Vlachos, A., Korkotian, E., Schonfeld, E., Copanaki, E., Deller, T., and Segal, M. (2009). Synaptopodin regulates plasticity of dendritic spines in hippocampal neurons. J Neurosci 29, 1017-1033.

von Koch, C.S., Zheng, H., Chen, H., Trumbauer, M., Thinakaran, G., van der Ploeg, L.H., Price, D.L., and Sisodia, S.S. (1997). Generation of APLP2 KO mice and early postnatal lethality in APLP2/APP double KO mice. Neurobiol Aging 18, 661-669.

Walters, B.J., and Josselyn, S.A. (2019). Retinoic acid receptor plays both sides of homeostatic plasticity. Proc Natl Acad Sci U S A 116, 6528-6530.

Westmark, C.J. (2013). What's hAPPening at synapses? The role of amyloid beta-protein precursor and beta-amyloid in neurological disorders. Mol Psychiatry 18, 425-434.

Weyer, S.W., Zagrebelsky, M., Herrmann, U., Hick, M., Ganss, L., Gobbert, J., Gruber, M., Altmann, C., Korte, M., Deller, T., and Muller, U.C. (2014). Comparative analysis of single and combined APP/APLP knockouts reveals reduced spine density in APP-KO mice that is prevented by APPsalpha expression. Acta Neuropathol Commun 2, 36.

Yan, R., and Vassar, R. (2014). Targeting the beta secretase BACE1 for Alzheimer's disease therapy. Lancet Neurol 13, 319-329.

Zhang, J., Hou, L., Gao, X., Guo, F., Jing, W., Qi, J., and Qiao, J. (2009). Amyloid $\beta$-protein differentially affects NMDA receptor- and GABAA receptor-mediated currents in rat hippocampal CA1 neurons. Progress in Natural Science 19, 963-972.

Zhao, D., Watson, J.B., and Xie, C.W. (2004). Amyloid beta prevents activation of calcium/calmodulin-dependent protein kinase II and AMPA receptor phosphorylation during hippocampal long-term potentiation. J Neurophysiol 92, 2853-2858.

Zheng, H., Jiang, M., Trumbauer, M.E., Sirinathsinghji, D.J., Hopkins, R., Smith, D.W., Heavens, R.P., Dawson, G.R., Boyce, S., Conner, M.W., et al. (1995). beta-Amyloid precursor protein-deficient mice show reactive gliosis and decreased locomotor activity. Cell 81, 525-531.

Zheng, H., and Koo, E.H. (2011). Biology and pathophysiology of the amyloid precursor protein. Mol Neurodegener 6, 27.

Zott, B., Simon, M.M., Hong, W., Unger, F., Chen-Engerer, H.J., Frosch, M.P., Sakmann, B., Walsh, D.M., and Konnerth, A. (2019). A vicious cycle of beta amyloid-dependent neuronal hyperactivation. Science $365,559-565$. 


\section{FIGURE TITLES AND LEGENDS}

Figure 1: Dentate granule cells of APP-deficient entorhinal-hippocampal tissue cultures do not express homeostatic synaptic plasticity

(A, B) Example of three-week old entorhinal-hippocampal tissue cultures on a membrane insert and overview at higher magnification of a representative culture. DAPI nuclear staining used for visualization of cytoarchitecture (DG, dentate gyrus; EC, entorhinal cortex; CA1 and CA3, Cornu Ammonis areas 1 and 3). Scale bar $500 \mu \mathrm{m}$. (C) Patched dentate granule cell filled with biocytin and identified post-hoc with streptavidin A488. Scale bar $25 \mu \mathrm{m}$. (D, E) Sample traces and group data of AMPA receptor mediated miniature excitatory postsynaptic currents (mEPSCs) recorded from granule cells in vehicle-treated (control) and tetrodotoxin (TTX)-treated $A P P^{+/+}$cultures (control, $\mathrm{n}=23$ cells from 6 cultures; TTX, $\mathrm{n}=33$ cells from 8 cultures; Mann-Whitney test). (F, G) Sample traces and group data of APP-deficient $\left(A P P^{-/-}\right)$ dentate granule cells (control, $n=20$ cells from 6 cultures; TTX, $n=25$ cells from 7 cultures; Mann-Whitney test). (H) Example of post-hoc identified recorded dentate granule cells (streptavidin 633, white) in an $A P P^{-/}$tissue culture transduced with adeno-associated viral vectors expressing full length APP (AAV-flAPP Venus; yellow). Scale bar $50 \mu \mathrm{m}$. (I) Expression of the flAPP rescues the ability of dentate granule cells in $A P P^{-/}$tissue cultures to express TTX-induced homeostatic synaptic plasticity (control, $\mathrm{n}=17$ cells from 6 cultures; TTX, $\mathrm{n}=20$ cells from 7 cultures; Mann-Whitney test). Individual data points are indicated in this and the following figures by grey dots. Values represent mean \pm s.e.m. $(* \mathrm{p}<0.05, * * * \mathrm{p}$ $<0.001 ; \mathrm{NS}$, no significant difference). 
Figure 2: APP deficiency does not affect basic functional properties of dentate granule cells

(A, B) Sample traces and group data of spontaneous excitatory postsynaptic currents (sEPSC) recorded from dentate granule cells of $A P P^{+/+}$and $A P P^{-/-}$tissue cultures $\left(A P P^{+/+}, \mathrm{n}=10\right.$ cells from 4 cultures, $A P P^{-/}, \mathrm{n}=20$ cells from 6 cultures; Mann-Whitney). (C, D) Sample traces and group data of spontaneous inhibitory postsynaptic currents (sIPSC) from granule cells of $A P P^{+/+}$and $A P P^{-/-}$tissue cultures $\left(A P P^{+/+}, \mathrm{n}=12\right.$ cells from 4 cultures, $A P P^{-/}, \mathrm{n}=18$ cells from 6 cultures; Mann-Whitney test). (E-G) Sample traces and group data for input-output properties of dentate granule cells of $A P P^{+/+}$and $A P P^{-/}$tissue cultures. (RMP, resting membrane potential, AP, action potential; $A P P^{+/+}, \mathrm{n}=19$ cells from 5 cultures, $A P P^{-/}, \mathrm{n}=20$ cells from 5 cultures; NS; Mann-Whitney test and 2way ANOVA). Values represent mean \pm s.e.m. (NS, no significant difference).

\section{Figure 3: No significant structural differences are observed in granule cells of APP-}

\section{deficient preparations}

(A - C) Examples and group data of total dendritic length and Sholl sphere analysis of dentate granule cells in $A P P^{+/+}$and $A P P^{-/-}$tissue cultures ( $\mathrm{n}=7$ cells from 7 cultures per group; NS; Mann-Whitney test and 2way ANOVA), scale bar $50 \mu \mathrm{m}$ (D, E) Spine density analysis of distal dendritic segments of dentate granule cells in the outer molecular layer (OML; $\mathrm{n}=18$ 19 segments from 6 tissue cultures per group; Mann-Whitney test). Scale bar $5 \mu \mathrm{m}$. (F) Electron micrograph of synaptic contacts in the OML of $A P P^{-/-}$tissue cultures. Examples of presynaptic compartments indicated by asterisks, postsynapses by circles. Scale bar $0.5 \mu \mathrm{m}$. Values represent mean \pm s.e.m. (NS, no significant difference). 
Figure 4: A secreted factor mediates the ability of APP-/- dentate gyrus granule cells to express homeostatic synaptic plasticity

(A) Example of co-cultured $A P P^{+/+}$and $A P P^{-/}$tissue preparations on the same membrane insert. (B, C) Sample traces and group data of AMPA receptor mediated miniature excitatory postsynaptic currents (mEPSCs) recorded from dentate gyrus granule cells in vehicle-treated (control) and tetrodotoxin (TTX)-treated $(2 \mu \mathrm{M}, 2 \mathrm{~d}) A P P^{-/-}$tissue cultures (control, $\mathrm{n}=10$ cells from 4 cultures; TTX, $\mathrm{n}=16$ cells from 5 cultures; Mann-Whitney test). Values represent mean \pm s.e.m. $(* * * \mathrm{p}<0.001 ; \mathrm{NS}$, no significant difference).

Figure 5: APPsa does not rescue the ability of APP-deficient dentate granule cells to express homeostatic synaptic plasticity

(A, B) Sample traces and group data of AMPA receptor mediated miniature excitatory postsynaptic currents (mEPSCs) recorded from granule cells in vehicle-treated (control) and tetrodotoxin (TTX)-treated $(2 \mu \mathrm{M}, 2 \mathrm{~d}) \mathrm{APP}^{-/-}$tissue cultures in the presence of recombinant APPs $\alpha(10 \mathrm{nM}$; control, $\mathrm{n}=17$ cells from 5 cultures; TTX, $\mathrm{n}=16$ cells from 5 cultures; Mann-Whitney test). (C, D) Sample traces and group data of AMPA receptor mediated mEPSCs from granule cells in APP-/- tissue cultures transduced with adeno-associated viral vectors expressing APPs $\alpha$ (control, $n=7$ cells; TTX, $n=8$ cells; from 2 cultures per group; Mann-Whitney test). (E, F) Sample traces and group data of AMPA receptor mediated mEPSCs from granule cells in tissue cultures prepared from APPs $\alpha$ knock-in (KI) mice (control, $\mathrm{n}=9$ cells from 3 cultures; TTX, $\mathrm{n}=14$ cells from 4 cultures; Mann-Whitney test; for mEPSC frequency one data point is outside the axis limits in the TTX group). Values represent mean \pm s.e.m. $(* * \mathrm{p}<0.01$; NS, no significant difference). 
(A) Group data of AMPA receptor mediated miniature excitatory postsynaptic currents of $A P P^{+/+}$dentate granule cells (control, $\mathrm{n}=19$ cells from 7 cultures; TTX, $\mathrm{n}=18$ cells from $<0.001$; NS, no significant difference).

871 (A, B) Group data of AMPA receptor mediated miniature excitatory postsynaptic currents 872 (mEPSC) recorded from granule cells in vehicle-treated (control) and tetrodotoxin (TTX)treated $(2 \mu \mathrm{M}, 2 \mathrm{~d}) A P P^{-/-}$tissue cultures in the presence of amyloid- $\beta_{1-42}\left(\mathrm{~A} \beta_{1-42} ; 1.5 \mu \mathrm{M}\right)$ or $\mathrm{A} \beta_{42-1}(1.5 \mu \mathrm{M})$. (A: control, $\mathrm{n}=16$ cells from 4 cultures; $\mathrm{A} \beta_{1-42}, \mathrm{n}=8$ cells from 3 cultures; $\mathrm{A} \beta_{1-42}+\mathrm{TTX}, \mathrm{n}=16$ cells from 5 cultures; Kruskal-Wallis-test followed by Dunn's post-hoc test; for mEPSC amplitudes one data point is outside the axis limits in the $A \beta_{1-42}+$ TTX group; $B: A \beta_{42-1}, n=16$ cells from 4 cultures; $A \beta_{42-1}+$ TTX, $n=17$ cells from 5 cultures; Mann-Whitney test). (C) Group data of AMPA receptor mediated mEPSCs recorded from granule cells in vehicle-treated (control) and TTX-treated $(2 \mu \mathrm{M}, 2 \mathrm{~d})$ wild-type tissue $20 \mu \mathrm{M})$ prevents TTX-induced synaptic scaling; an effect that is reversed with $\mathrm{A} \beta_{1-42}(1.5$. $\mu \mathrm{M})$. Untreated: control, $\mathrm{n}=17$ cells from 5 cultures; TTX, $\mathrm{n}=16$ cells from 4 cultures. $\beta$ secretase inhibitor: control, $\mathrm{n}=9$ cells from 3 cultures; TTX, $\mathrm{n}=25$ cells from 7 cultures; 
test). (D) Group data of AMPA receptor mediated mEPSCs recorded from granule cells in vehicle-treated (control) and TTX-treated $(2 \mu \mathrm{M}, 2 \mathrm{~d}) A P P^{-/-}$preparations co-cultured with $A P P^{+/+}$tissue (c.f., Figure 4). BACE inhibitor C3 $(20 \mu \mathrm{M})$ prevents TTX-induced synaptic scaling (control, $\mathrm{n}=16$ cells from 5 cultures; TTX, $\mathrm{n}=17$ cells from 5 cultures; NS; MannWhitney test). (E) Pharmacological inhibition of $\gamma$ - secretases with Begacestat $(1 \mu \mathrm{M})$ prevents TTX-induced synaptic scaling of dentate granule cells in wild-type tissue cultures; an effect that is reversed with $A \beta_{1-42}(1.5 . \mu M)$. control, $n=13$ cells from 4 cultures; TTX, $n=$ 18 cells from 6 cultures; $\mathrm{A} \beta_{1-42}+\mathrm{TTX}, \mathrm{n}=18$ cells from 6 cultures; Kruskal-Wallis-test followed by Dunn's post-hoc test). (F) In the presence of a specific anti-A $\beta$ antibody (1.3 $\mu \mathrm{g} / \mathrm{ml}$ ) TTX-induced synaptic scaling is not observed (results of the experiments in wild-type tissue reported in the main text; $\mathrm{n}=16$ cells from 6 cultures in each group; Mann-Whitney test). Values represent mean \pm s.e.m. $(* \mathrm{p}<0.05$; *** $\mathrm{p}<0.001$; NS, no significant difference).

\section{Figure 8: Role of $\mathrm{Ca}^{2+}$ signaling and synaptopodin in APP/amyloid- $\beta$ mediated}

\section{homeostatic synaptic scaling.}

(A, B) Sample traces and group data of AMPA receptor mediated miniature excitatory postsynaptic current (mEPSCs) recorded from granule cells in D-APV (50 $\mu \mathrm{M} ; 2 \mathrm{~d})$ treated and D-APV $(50 \mu \mathrm{M})+$ TTX-treated $(2 \mu \mathrm{M}, 2 \mathrm{~d}) A P P^{-/}$tissue cultures (D-APV, $\mathrm{n}=10$ cells from 3 cultures; TTX + D-APV, $n=16$ cells from 4 cultures; Mann-Whitney test). (C) Group data of AMPA receptor mediated mEPSCs from granule cells in $A P P^{-/}$cultures recorded in the presence of the calcium/calmodulin-dependent protein kinase II (CamKII) inhibitor KN93 or the inactive analogue KN92 (KN93: control, $\mathrm{n}=18$ cells from 5 cultures; TTX $=20$ cells from 5 cultures; KN92: control, $\mathrm{n}=17$ cells from 5 cultures; TTX $=16$ cells from 5 cultures; one data point in mEPSC frequency outside the axis limits; NS; Mann-Whitney test). (D) Example of a $A P P^{-/}$tissue cultures immunostained for synaptopodin (Synpo, green). Cluster 
910

911

912

913

914

915

916

917

918

919

920

921

922

923

sizes were assessed in the outer molecular layer (oml) of the dentate gyrus. (iml, inner molecular layer; gcl, granule cell layer; DAPI, nuclear stain). Scale bar $=50 \mu \mathrm{m}$. (E) Examples of analysed visual fields (six fields per culture and condition) at higher magnification. All treatments 2 days. TTX, $2 \mu \mathrm{M}$; $\mathrm{A} \beta_{1-42}, 1.5 \mu \mathrm{M}$; D-APV, $50 \mu \mathrm{M}, \mathrm{KN} 93,5$ $\mu \mathrm{M}$. Scale bar $5 \mu \mathrm{m}$ (F) Group data of synaptopodin cluster sizes in the respective groups. Values normalized to controls (control, $n=7$ cultures; TTX, $n=6$ cultures; TTX $+A \beta_{1-42,} n=$ 7 cultures; TTX + D-APV, $n=6$ cultures; TTX + KN93, $n=6$ cultures; Kruskal-Wallis-test followed by Dunn's post-hoc test). (G) Group data of AMPA receptor mediated mEPSCs recorded from granule cells in synaptopodin-deficient $\left(S Y N P O^{-/}\right)$tissue cultures. $\mathrm{A} \beta_{1-42}(1.5$ $\mu \mathrm{M}, 2 \mathrm{~d}$ ) does not rescue TTX-induced homeostatic synaptic plasticity (untreated, $\mathrm{n}=17$ cells from 6 culltures; TTX, $\mathrm{n}=16$ cells from 5 cultures; TTX $+\mathrm{A} \beta_{1-42}, \mathrm{n}=17$ cells from 5 cultures; Kruskal-Wallis-test followed by Dunn's post-hoc test). Values represent mean \pm s.e.m. $(* \mathrm{p}<0.05 ; * * \mathrm{p}<0.01 ; * * * \mathrm{p}<0.001 ; \mathrm{NS}$, no significant difference).

\section{Figure 9: Possible implications for APP processing in synaptic plasticity}

A firm link between the non-amyloidogenic processing pathway (i.e., APP secreted ectodomain APPs $\alpha$ and the ability of neurons to express long-term potentiation of excitatory neurotransmission has been established. The results of the present study show that the amyloidogenic processing pathway, which produces amyloid- $\beta(\mathrm{A} \beta)$ may serve homeostatic synaptic plasticity. It is thus interesting to speculate, that signaling pathways that influence APP processing via $\beta$-secretase or $\gamma$-secretases may set a balance between Hebbian and homeostatic synaptic plasticity in neural networks 


\section{$A$

\section{CA3 DG}

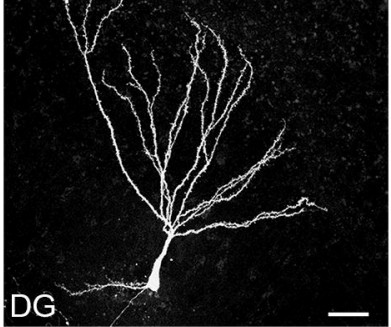

D $A P P^{+/+}$

control

COn

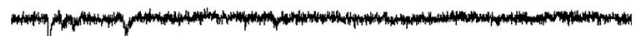

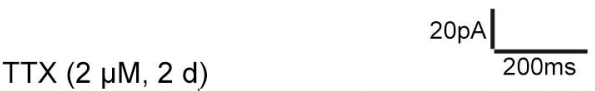

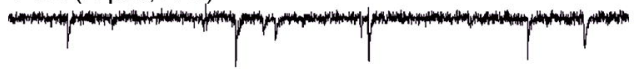

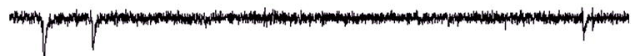

F $A P P^{-1-}$

control

con

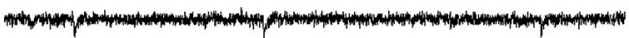

$\operatorname{TTX}(2 \mu \mathrm{M}, 2 \mathrm{~d})$

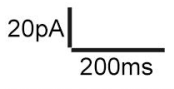

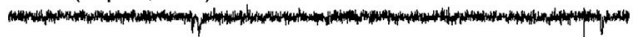

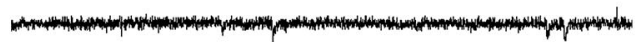

$\mathrm{H}$

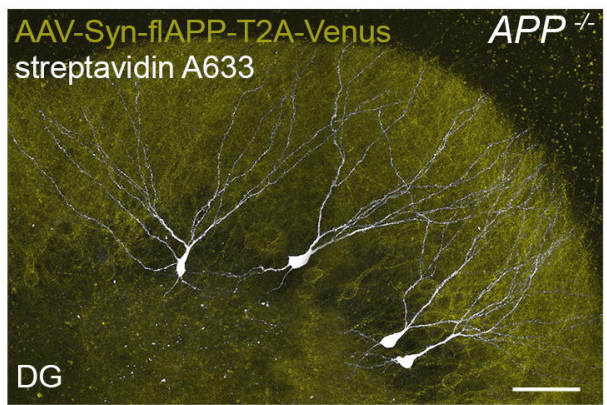

E
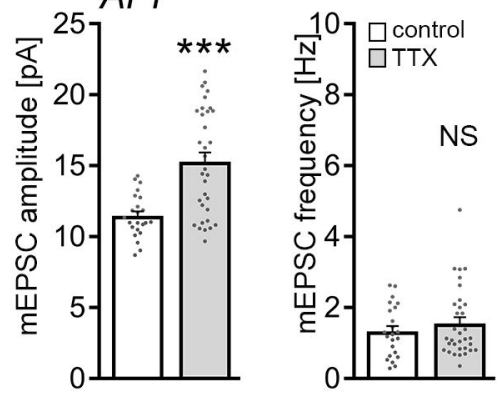

$G$

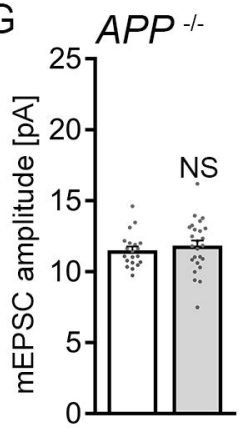

Figure 1

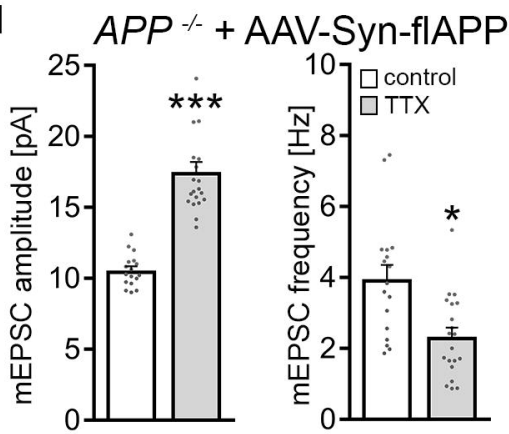


$\mathrm{A}_{A P P^{+/+}}$

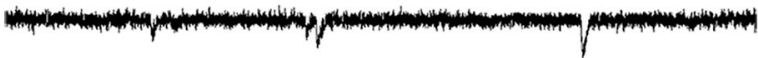

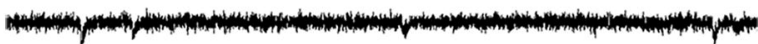

$A P P^{-/-} \quad 20 \mathrm{pA} \frac{}{200 \mathrm{~ms}}$

OAn

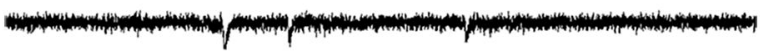

C

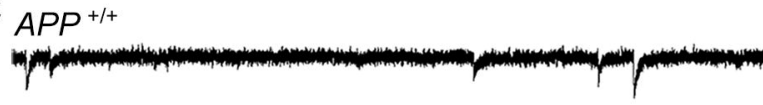

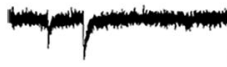

$A P P^{-/-}$
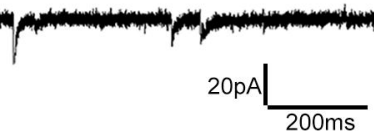

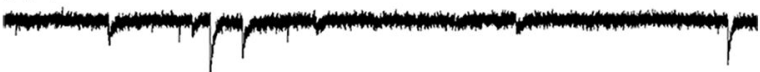

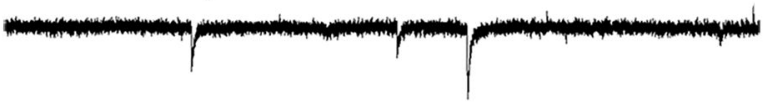

$E$

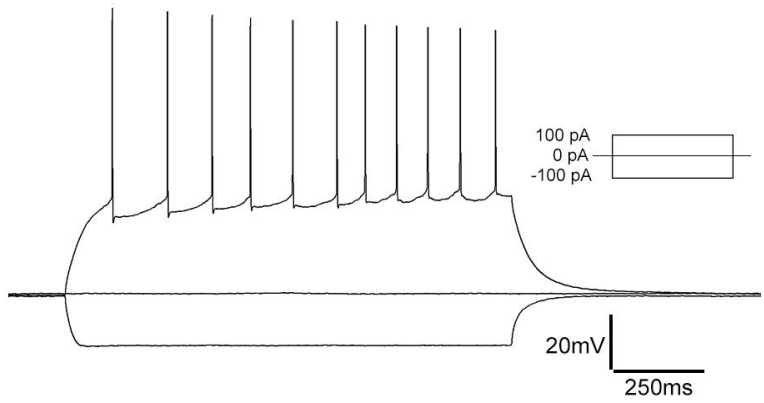

G

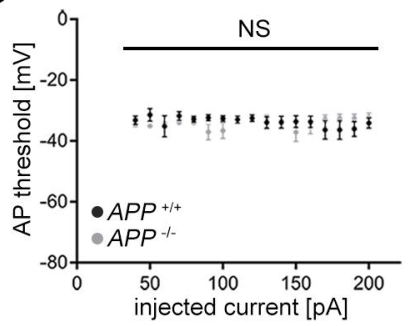

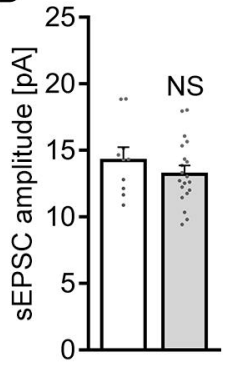

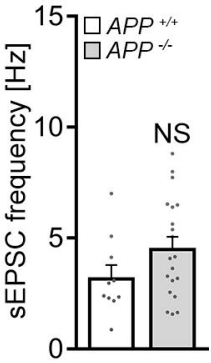

$D$
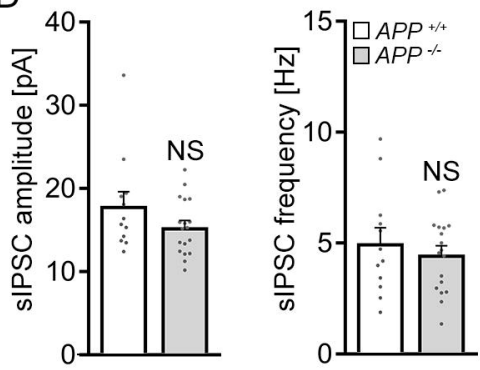

F
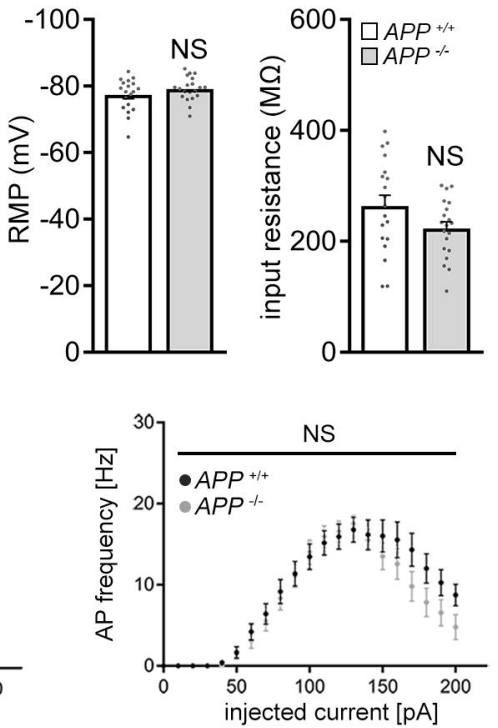

\section{Figure 2}


A

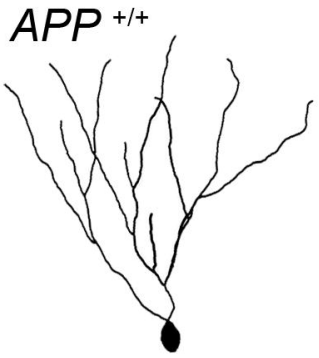

$A P P^{-1-}$

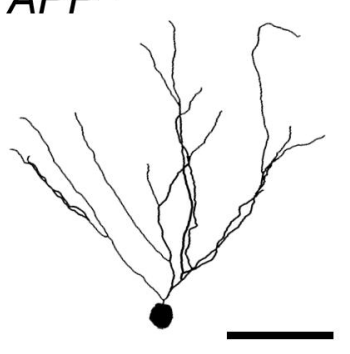

D

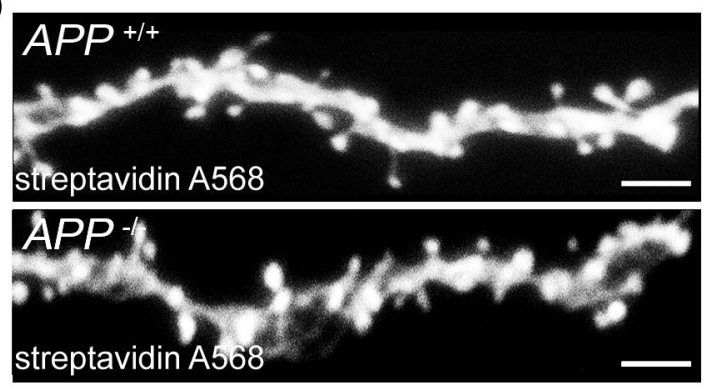

B

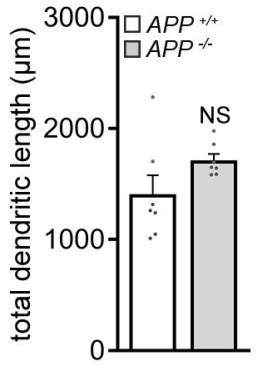

E

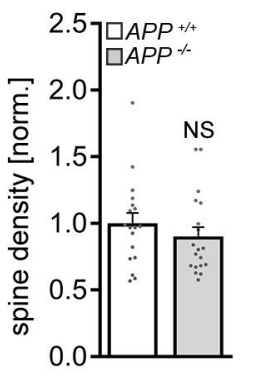

C 15 पAPP $+1+$

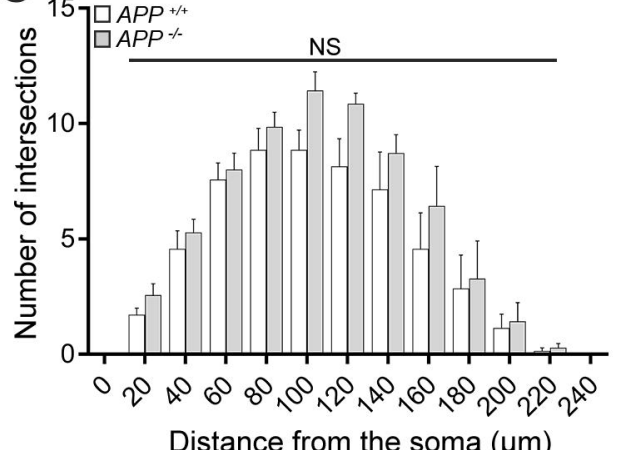

F

Figure 3 


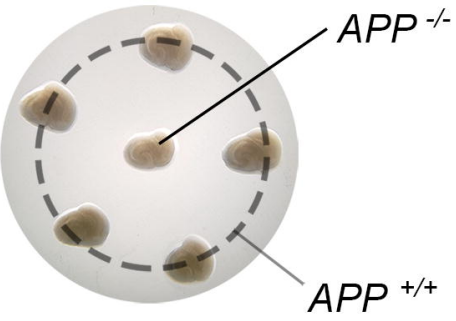

B

control

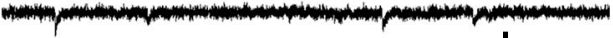

$\operatorname{TTX}(2 \mu \mathrm{M}, 2 \mathrm{~d})$

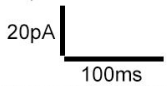

C

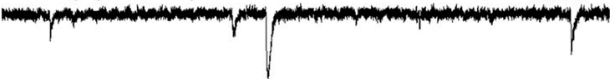

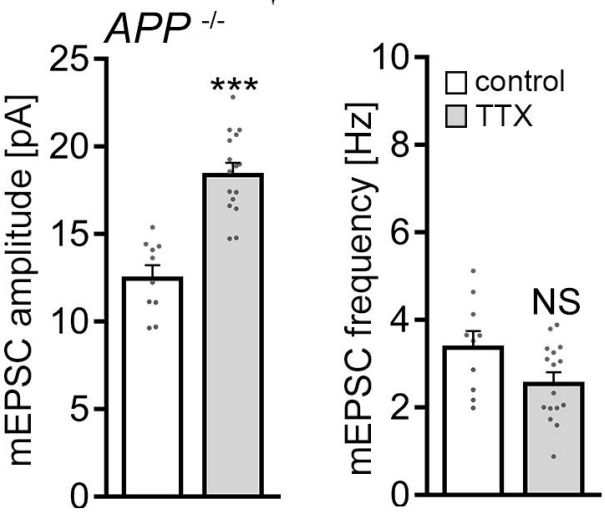

\section{Figure 4}




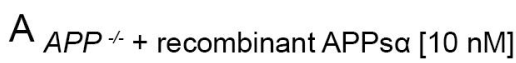

control

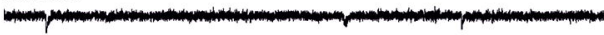

(1)

$\operatorname{TTX}(2 \mu \mathrm{M} ; 2 \mathrm{~d})$

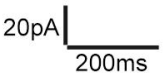

(1)

movim

$\mathrm{C}_{\mathrm{APP}} \%+\mathrm{AAV}-\mathrm{APP} \mathrm{sa}$

control

.

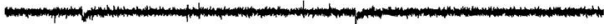

$\operatorname{TTX}(2 \mu \mathrm{M} ; 2 \mathrm{~d})$

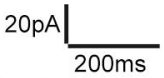

1)

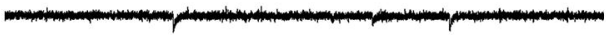

E APPsa KI

control

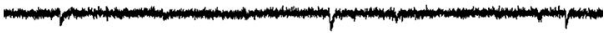

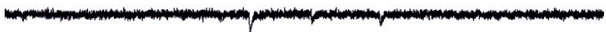

TTX (2 $\mu \mathrm{M} ; 2$ d)

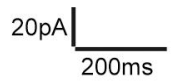

Figure 5

B $A P P^{\%}+$ recombinant APPsa [10 nM]

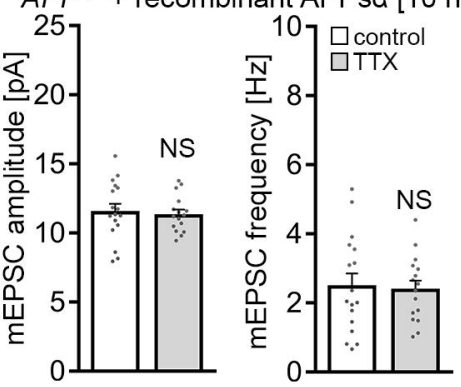

D $A P P \%+$ AAV-APPsa

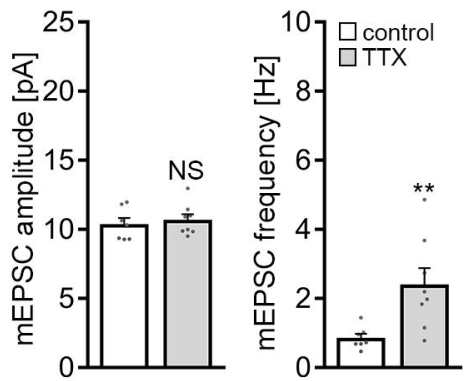

F APPsa KI

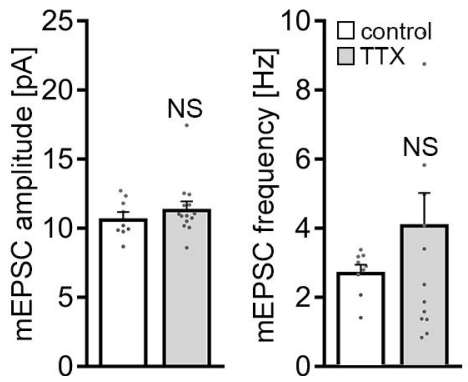


A $\quad \mathrm{APP}^{+/+}$

B $\quad$ APP $^{+/+}$
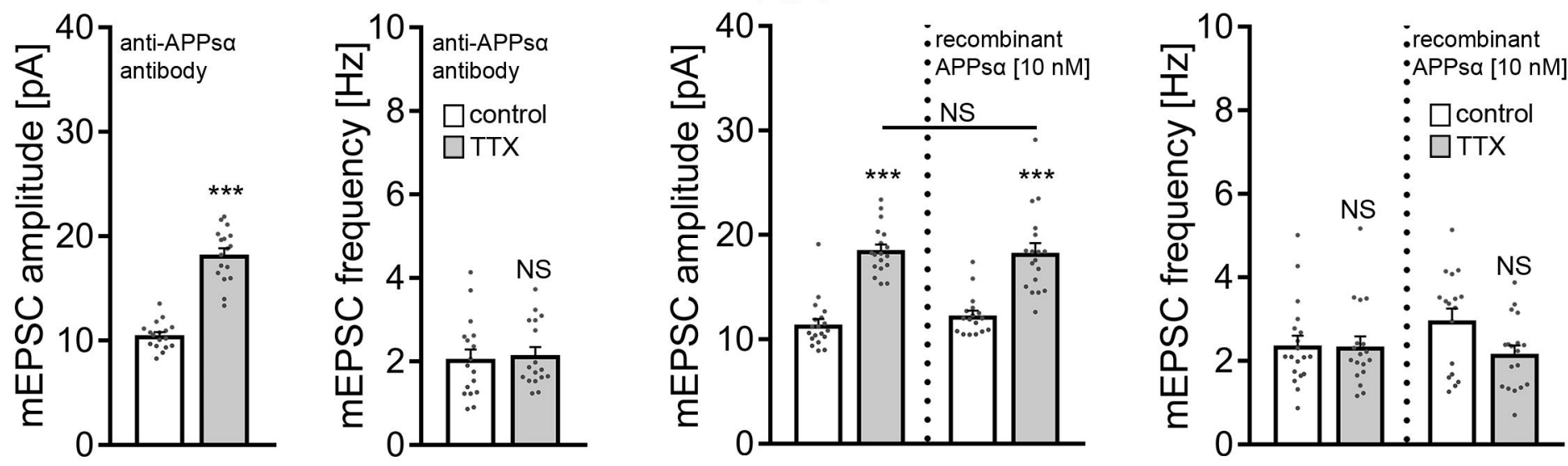

Figure 6 


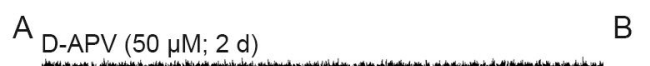

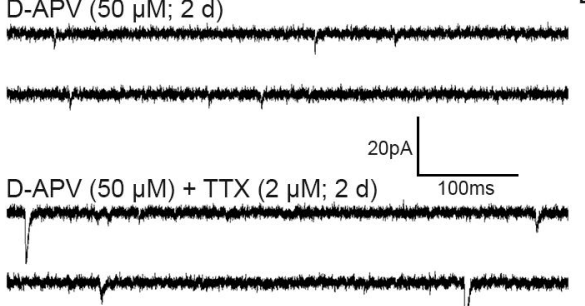

C
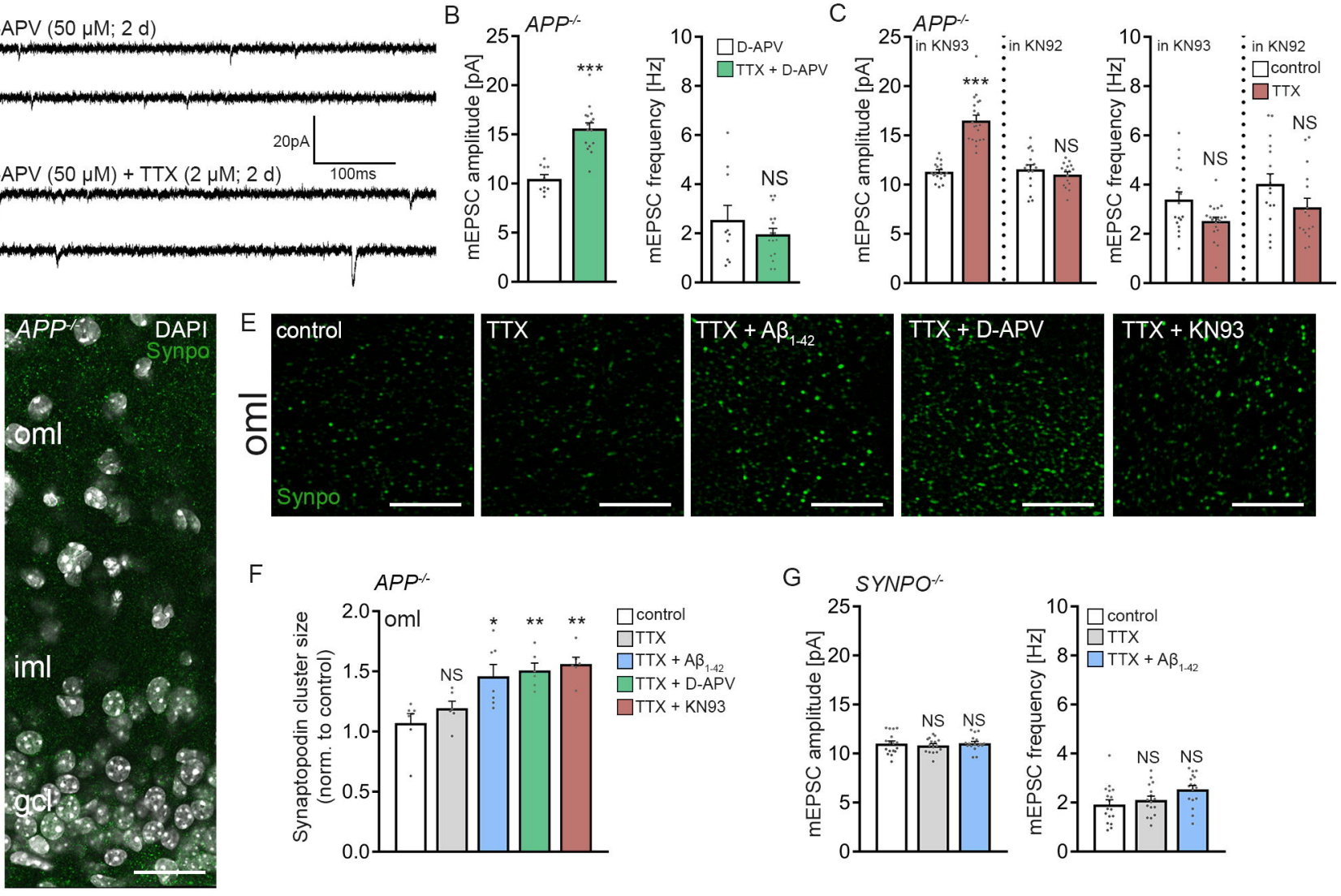

F
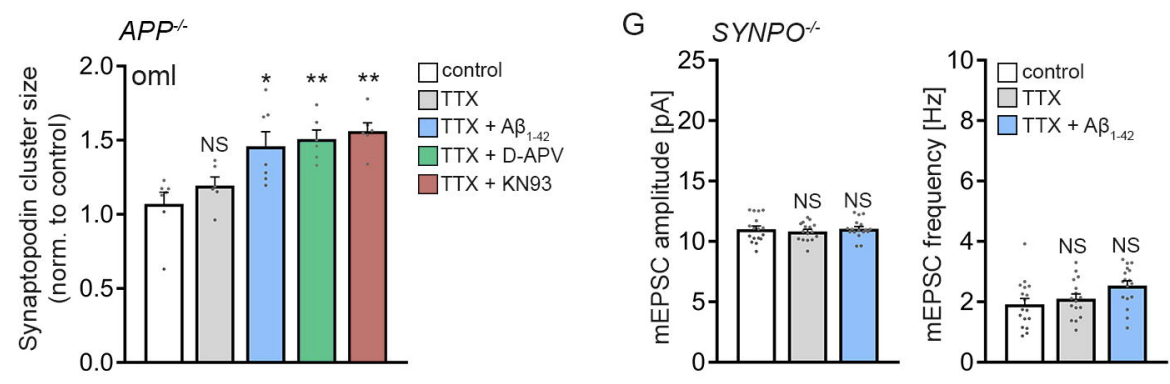

Figure 8 
non-amyloidogenic processing

Hebbian synaptic plasticity amyloidogenic processing

Homeostatic synaptic plasticity

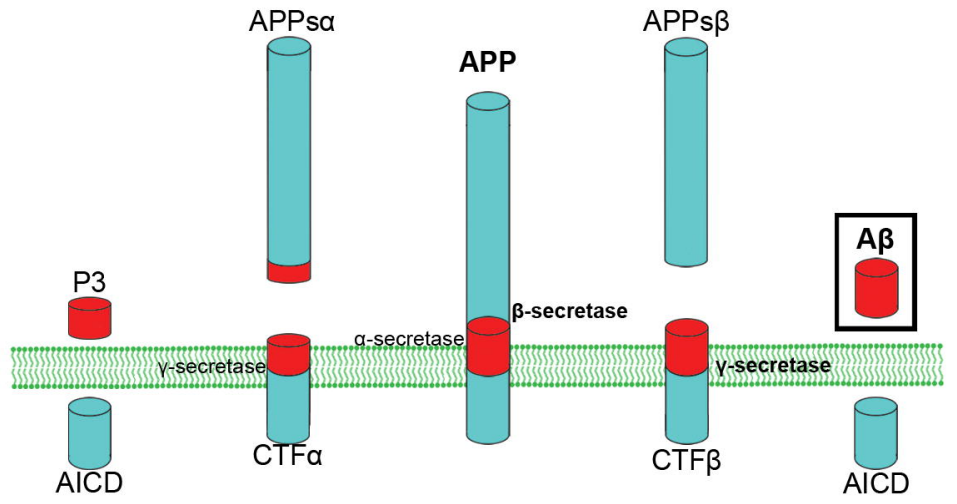

Figure 9 